\title{
The Two Weapons against Bacterial Biofilms: Detection and Treatment
}

\author{
Adriana Cruz ${ }^{1,2}$, Manuel Condinho ${ }^{3}$, Beatriz Carvalho ${ }^{3}$, Cecília M. Arraiano ${ }^{3}$, Vânia Pobre ${ }^{3, *(D)}$ \\ and Sandra N. Pinto $1,2, *$ (D)
}

1 iBB - Institute for Bioengineering and Biosciences, Instituto Superior Técnico, University of Lisbon, Av. Rovisco Pais, 1049-001 Lisboa, Portugal; adriana.b.cruz@tecnico.ulisboa.pt

2 i4HB-Institute for Health and Bioeconomy, Instituto Superior Técnico, University of Lisbon, Av. Rovisco Pais, 1049-001 Lisboa, Portugal

3 Instituto de Tecnologia Química e Biológica António Xavier, Universidade Nova de Lisboa, Av. da República, 2780-157 Oeiras, Portugal; manuel.condinho@itqb.unl.pt (M.C.); beatriztdcarvalho@gmail.com (B.C.); cecilia@itqb.unl.pt (C.M.A.)

* Correspondence: vaniapobre@itqb.unl.pt (V.P.); sandrapinto@ist.utl.pt (S.N.P.)

Citation: Cruz, A.; Condinho, M.; Carvalho, B.; Arraiano, C.M.; Pobre, V.; Pinto, S.N. The Two Weapons against Bacterial Biofilms: Detection and Treatment. Antibiotics 2021, 10, 1482. https://doi.org/10.3390/ antibiotics10121482

Academic Editor: Raymond J. Turner

Received: 12 November 2021

Accepted: 1 December 2021

Published: 3 December 2021

Publisher's Note: MDPI stays neutral with regard to jurisdictional claims in published maps and institutional affiliations.

Copyright: (c) 2021 by the authors. Licensee MDPI, Basel, Switzerland. This article is an open access article distributed under the terms and conditions of the Creative Commons Attribution (CC BY) license (https:// creativecommons.org/licenses/by/ $4.0 /)$.

\begin{abstract}
Bacterial biofilms are defined as complex aggregates of bacteria that grow attached to surfaces or are associated with interfaces. Bacteria within biofilms are embedded in a self-produced extracellular matrix made of polysaccharides, nucleic acids, and proteins. It is recognized that bacterial biofilms are responsible for the majority of microbial infections that occur in the human body, and that biofilm-related infections are extremely difficult to treat. This is related with the fact that microbial cells in biofilms exhibit increased resistance levels to antibiotics in comparison with planktonic (free-floating) cells. In the last years, the introduction into the market of novel compounds that can overcome the resistance to antimicrobial agents associated with biofilm infection has slowed down. If this situation is not altered, millions of lives are at risk, and this will also strongly affect the world economy. As such, research into the identification and eradication of biofilms is important for the future of human health. In this sense, this article provides an overview of techniques developed to detect and imaging biofilms as well as recent strategies that can be applied to treat biofilms during the several biofilm formation steps.
\end{abstract}

Keywords: bacterial biofilms; biofilm detection; biofilm imaging; antimicrobial treatment; antibiofilm agents

\section{Introduction}

Antimicrobial resistance is the inevitable consequence of prescribing antibiotics, and bacteria will continue to develop resistance to therapies. This is a critical problem in hospital environments in particular due to the low numbers of novel compounds or strategies under development [1]. Several factors contribute to this scarcity, including a market failure, produced by the lack of incentive for pharmaceutical companies to develop antibiotics. This lack of incentives for development of novel antibiotics is a result of a low return on investment, since they are fast-acting drugs, use of novel antibiotics is often reserved, and their use is ultimately unpredictable as resistance evolves [1].

A 2014 report commissioned by the U.K. government also predicted that millions of people are expected to die prematurely because of drug resistance over the next 35 years worldwide and the world's gross domestic product (GDP) will be 2 to $3.5 \%$ lower than it otherwise would be in 2050 [2].

This problem is even more relevant when is associated with bacterial biofilms, since bacteria growing in biofilms show significantly reduced antibiotic susceptibility. For instance, implant-related infections are very hard to treat [3]. This is due to the fact that clinical procedures to treat implant-related infections involve replacement of the implant 
that can increase the risk for the patient developing severe complications, as well as the very high costs associated with this procedure [4].

Bacterial biofilms consist of densely packed communities that grow attached to surfaces and are responsible for the majority of human clinical infections $[5,6]$. Their resistance to conventional antibiotics is 10- to 1000-fold higher than that of planktonic bacteria [7].

This increased resistance can be attributed to different factors, including decreased diffusion of antimicrobial agents through the self-produced extracellular matrix (made of polysaccharides, nucleic acids, and proteins matrix) [8-10], altered metabolic activity, and formation of persister cells [11]. Moreover, a relevant characteristic of biofilms is the fact that bacteria are able to inter-communicate and collaborate to survive in even the hardest conditions. This cell-cell communication mechanism is known as the quorum sensing (QS) system [12]. Bacteria QS system consists of self-produced extracellular chemical signals (called autoinducers), and it can control important virulence factors such as biofilm formation and maturation, antibiotic resistance, bacterial swarming, and bacteria-host interaction $[12,13]$.

Altogether, bacteria biofilms are hard to eradicate and can cause severe infections, and the increasing numbers of infections by antibiotic-resistant strains are expected to strongly impact the future of world economies.

In the light of this dark scenery, this review focuses on recent antibacterial and antibiofilm strategies and the state of the art of imaging techniques that are being used to study this bacterial lifestyle with the hope that the current situation can be altered in a near and brighter future.

\section{Imaging of Biofilms and the Diversity of Detection Methods}

Currently, nuclear medicine imaging is still the standard technique for the detection of infectious diseases [14]. However, this technique has several drawbacks, including the fact that (i) it involves the exposition of the patient to radiation, (ii) it requires specialized equipment, and (iii) it requires operator training.

As recognized, there is an urgency to develop more accurate diagnostic tools and treatment, particularly when bacterial infection progresses to biofilm. The noninvasive technique in clinical use does not offer an optimized approach to detect biofilm infection. The low resolution, low practicality, and impossibility to distinguish between bacterial infection and sterile inflammation are the reasons to develop new diagnostics tools for biofilm detection in clinical environments [15]. In the last few years, development of diagnostic approaches became urgent in order to improve the treatment of bacterial infections and preserve some medical procedures that need alternative tools to prevent and treat bacterial infections.

Considering this, in this topic, we highlight some of the possibilities for the detection and imaging of bacterial biofilms.

\subsection{Nuclear Imaging}

Nuclear imaging has been applied in oncology and in infectious disease diagnostics. Some radionuclides such as technetium- $-99 \mathrm{~m}$, iodide- 125 , and indium- 111 have been shown for years to be useful tools to radiolabeled compounds for medical applications [16].

However, some disadvantages are found in common bacterial imaging agents such as difficult radiochemical synthesis, non-specific adsorption, or small target receptor expression on bacteria of interest [16]. Despite these limitations, recent works have revealed that there are bacterial metabolites that can be radiolabeled and used as tracers to identify bacterial biofilm infections, such as the maltodextrin transport system [17,18].

The carbohydrate transport and metabolism has been reported as an essential tool for proliferation of bacteria in the human organism. Thus, there are some strategies that include carbohydrate metabolism as a target that can be very helpful in improving nuclear imaging in the field of infectious disease diagnostics. For instance, ${ }^{18} \mathrm{FDG}$ (fluorodeoxyglucose) is one example of an important radiopharmaceutical that has been used for many years on 
positron emission tomography (PET). However, ${ }^{18}$ FDG as a contrast agent shows a high uptake in mammalian cells and absence of distinguishing bacterial infections from cancer or inflammation $[19,20]$.

Although efforts are being made to find new radiopharmaceutical and contrast agents, there are some complications associated with radiochemical synthesis and low affinity/specify at the bacteria target. With the aim of increasing the sensitivity of currently imaging methods, researchers have developed other contrast agents targeting the bacterial carbohydrate metabolism. This is the case of ${ }^{18} \mathrm{~F}$-maltohexaose $\left(\mathrm{MH}^{18} \mathrm{~F}\right)$ [17]. $\mathrm{MH}^{18} \mathrm{~F}$ nuclear imaging agent is internalized by a bacteria-specific maltodextrin transporter. Thus, the contrast agents conjugated with maltohexose were only internalized by bacterial cells and not by mammalian cells, which do not express maltodextrin transporters [21]. Moreover, one of the major advantages of maltodextrin-based compounds is their lower toxicity because they are widely used as food additives. The development of nuclear agents such as $\mathrm{MH}^{18} \mathrm{~F}$ might be crucial to bacterial biofilm detection at an early stage.

\subsection{Ultrasound Contrast Agent Imaging}

Ultrasonic imaging techniques and their combination with other methods have been explored in order to enhance the strategies to detect and quantify early and mature biofilms [22,23]. The acoustic approach has the advantage of monitoring the surface biofouling in real time, and it has been proved that the ultrasonic technique can monitor formation and growth of some microbiological colonies [22].

Ultrasound medical imaging has been developed with the addition of contrast agents, especially encapsulated gas bubbles, which has led to an improvement in medical diagnosis [24]. Another improvement was a novel design of ultrasound contrast agents (UCAs), including a target ligand to establish the difference between infectious and healthy tissue [25].

It is important to have a detection technique that allows for identification of biofilms in early stages because the late diagnostic of mature biofilms sometimes compromises their clinical treatment inside the human body. Echocardiography, for instance, has several limitations in the detection of intra-cardiac biofilm. Staphylococcus aureus is the most common isolate in infective endocarditis, and strategies have been developed that can evaluate and characterize mechanical and structural properties of its biofilm. In this sense, researchers have developed strategies that could be evaluated and that characterize mechanical and structural properties of S. aureus biofilm [26]; this is because S. aureus is the most common isolate in infective endocarditis [27]. S. aureus biofilm has been studied through a combination of targeted ultrasound contrast agents (UCAs) and fluorescent probes. In the first step, developed UCAs that bind a carbohydrate epitope allowed for a spatial scanning of biofilm structure by high-frequency scanning acoustic microscopy (SAM). A complementary analysis occurred with TRITC-labelled streptavidin by fluorescence microscopy. The merge between high-frequency acoustic scanning and fluorescence imaging allowed for the acquisition of spatial resolution and detection of the biofilm components [26]. The results obtained showed an improvement in biofilm diagnostics.

\subsection{Optical Imaging and Probes}

Optical imaging offers an important tool to understand/visualize the 3D biofilm structure. Multiple techniques are included in this range, such as scanning electron microscopy (SEM), confocal scanning laser microscopy (CSLM), light microscopy, infrared spectroscopy, and reflectance spectroscopy [28]. Figure 1 illustrates a S. aureus biofilm visualized with the use of CSLM and SEM. 
SYTO 9

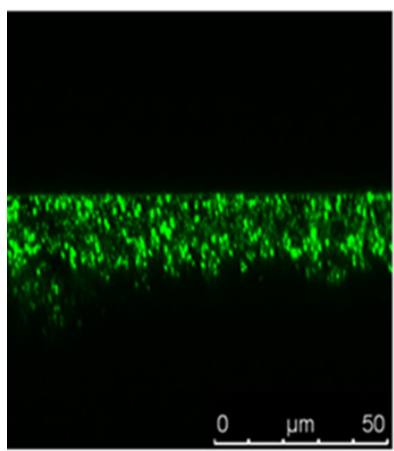

WGA-Alexa 633

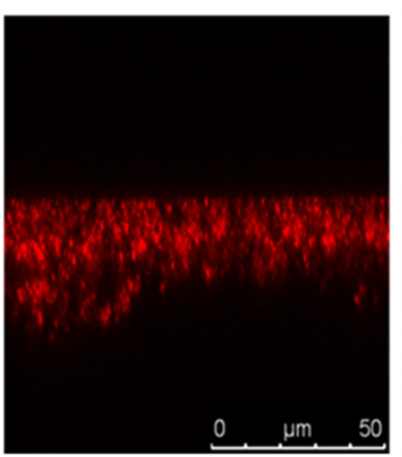

Overlay

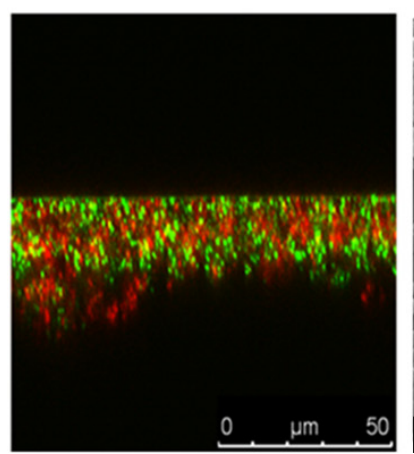

FEG-SEM

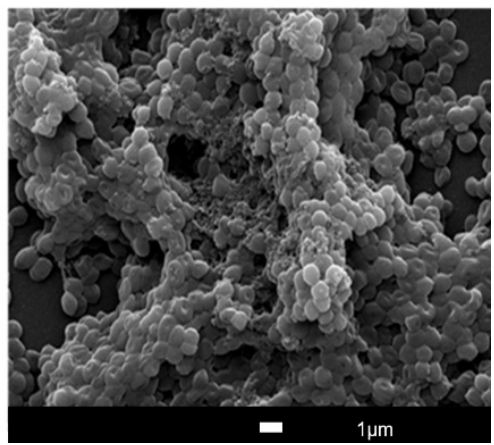

Figure 1. Imaging of bacterial biofilms with confocal scanning laser microscopy (CSLM) and SEM. Twenty-four hour S. aureus JE2 (MRSA) biofilm was co-labelled with SYTO 9 (green channel), a nucleic acid binding dye, and with WGAALEXA 633 (red channel), a wheat germ agglutinin dye that labels S. aureus biofilm matrix. The overlay between the two channels is also represented. In the right image, there is a representation scanning electron image (SEM) of $24 \mathrm{~h} \mathrm{S.} \mathrm{aureus}$ JE2 biofilms.

SEM, a technique with high resolution that is based on surface scattering and absorption of electrons, has been used in different studies to visualize biofilms (Figure 1) since it is able to detect key structural components such as the presence of biofilm matrix [29,30]. Moreover, researchers have been using SEM to evaluate the efficacy of anti-biofilm compounds [31-33]. However, SEM is a very expensive technique, and quantitation of the biofilm is rather difficult, including the fact that researchers cannot work with live samples.

Due to this, the most common used methodology to study the 3D biofilm morphology of biofilms is probably CSLM, and in fact, it is recognized that CSLM represents an important advance in technology-associated biofilm imaging [34]. In CSLM, due to the presence of a confocal pinhole, the out-of-focus fluorescent signals are eliminated [35], which is relevant when it is considered for instance with traditional fluorescent microscopy. Moreover, it allows for the formation of high-resolution images at different depths [36], which is crucial in biofilm studies. The tridimensional morphology and physiology of biofilms can then be screened by CLSM using a combination of molecular probes and fluorescent proteins optimized to target/visualize biofilm components. Most probes and fluorescent proteins are designed to stain cellular organelles and structures. However, in the last decades, there has been an effort in the development of proteins and fluorochromes to target, for instance, the extracellular matrix of biofilms. This includes the application of fluorescently labelled lectins (Figure 1) to visualize and characterize the biofilm matrix, in particular the extracellular polysaccharide components [37-39].

Extracellular DNA (eDNA) is also often a target for extracellular matrix imaging using CSLM. Propidium iodide, TOTO-1, and TO-PRO-3 iodide are probes that were used in this context, providing excellent distinction between biofilm eDNA component and the intracellular DNA found in biofilm cells $[8,40]$. These probes are often used in combination with SYTO 9 [8] or SYTO 60. SYTO 9 is a green fluorescent nucleic acid-binding dye. The fact that SYTO 9 is a membrane-permeable probe and TO-PRO-3 iodide or propidium iodide can only label cells with damaged membranes allows the viewer to discriminate between viable and nonviable cells [8].

Other fluorescent probes for extracellular DNA (eDNA) detection have recently been developed. This is the case of CDr15 probe, which was evaluated on Pseudomonas aeruginosa $\Delta \mathrm{wspF}$ with a highly elevated cyclic-di-GMP content (mimicking the biofilm mode of growth) and a pYhjH strain with a low intracellular cyclic-di- GMP content (representative of the planktonic mode of growth). The results showed that CDr15 probes bind effectively to eDNA. The robustness of CDr15 as a diagnostic in vivo probe was evaluated on corneal infection model, and the results showed that biofilm regions were visualized after CDr15 treatment [41]. 
Identification of novel fluorescent probes together with targeting different biofilm structures will greatly facilitate diagnosis of biofilm infection. In this sense, a fluorescent probe, CDy11, that targets amyloid-like fibers in the P. aeruginosa biofilm matrix was developed. It was demonstrated that $\mathrm{CDy} 11$ allows for detection using in vivo imaging of P. aeruginosa in implant and corneal infection mice models [42]. In addition, CDy14 was identified as a potential fluorescent probe to target Psl exopolysaccharide in P. aeruginosa [43]. In this context, amphiphilic fluorescent carbon dots were developed and applied to assist the characterization of bacterial biofilm matrix [44]. The amphiphilic carbon dots (C-dots) were shown to readily bind to the EPS scaffold of P. aeruginosa, and it was detected for the first time as a dendritic morphology of the EPS.

Furthermore, the peptide nucleic acid fluorescence in situ hybridization (PNA FISH) technique has also been used to study biofilm's structure and composition. Traditional FISH is a molecular technique on which labeled DNA probes hybridize to their complementary nucleic acid targets. The use of FISH (namely, DNA probes) to study microorganisms and biofilms can lead to some drawbacks, including poor target site specificity and poor signal-to-noise ratio [45,46]. The limitations associated with FISH can be overcome with the use of peptide nucleic acid (PNA) probes; PNA is a synthetic DNA analogue with a stronger binding to nucleic acids [47]. PNA FISH technique is very helpful for the CLSM observation of mixed biofilms since it allows for the use of multiple fluorescent probe labels that are characteristic of a specific microorganism [48,49].

Researchers have been using other methods besides PNA FISH in order to study complex biofilm structures such as those observed in mixed-biofilm populations. One method that is very popular involves the use of mutants expressing green fluorescent protein (GFP) and its variants [50-55]. The spatial-temporal fluorescence profiles of two or more fluorescent proteins constitutively expressed in biofilms was already successfully shown in biofilms prepared under dynamic flow conditions [56]. The combination of realtime CLSM imaging of biofilms expressing fluorescent proteins with flow systems allows for the acquisition of important and precise information regarding bacterial cell division and biofilm growth conditions and dynamics. Moreover, when biofilms are prepared under flow systems (including the use of microfluidic devices [57,58]), it is possible to obtain biofilms with a higher maturity degree such as mushroom-like structures found in P. aeruginosa biofilms [59]. Furthermore, the bond between the bacterial cells to the substratum surface is reported to be stronger when compared with static conditions [60]. The use of GFP and other variants in these real-time imaging studies is extremely helpful, but there are some artifacts caused by environmental factors that can have a negative impact in these assays, such as poor fluorescence at low $\mathrm{pH}$ and $\mathrm{O}_{2}$-dependence $[56,61]$.

In vivo biofilm detection possesses a challenge for the scientific community. One promising approach for this purpose relies on the use of laser capture microdissection (LCM). Laser capture microdissection is a high-resolution technique that allows researchers to rapidly sample/isolate individual cells or cell compartments from solid tissue with the aid of a laser beam [62,63]. LCM has also been used to isolate non-cellular structures including amyloid plaques [64]. This microdissection technique is often used in cancer research, e.g., [65], and now researchers are using it to obtain information related with in vivo biofilms. For instance, very recently, the adaptation of B. cereus in G. mellonella gut infection model was demonstrated for the first time with LCM [66].

Another valuable imaging technique for identification of in vivo biofilms is target fluorescent imaging (TFLI). The principle of TFLI is targeting fluorophores that emit light outside the absorbance window of tissue in the near infrared region. There are some reports of targeting fluorescent imaging for tumor diagnostics, and the first clinical TFLI approach employment was observed in ovarian cancer surgery [67]. Furthermore, some studies have been published to also demonstrate the ability of TFLI for in vivo detection of bacteria $[68,69]$. Since TFLI emerged as useful tool for multiple diagnosis in clinical research, Marleen van Osteen and colleagues decided to combine the TFLI advantages with vancomycin's well-known biodistribution profile. In this sense, the authors developed 
vanc-800CW as a new conjugate for optical biofilm imaging. For this propose the authors conjugated vancomycin with IRDye- $800 \mathrm{CW}$, a near-infrared fluorophore. The images were obtained by IVIS Lumina II imaging system [70].

The vanc-800CW potential as a fluorescent probe was evaluated in multiple models. The in vitro studies performed demonstrate a good detection for Streptococcus and Dermabacter species and minor detection of Corynebacterium. As expected, the results also confirmed the lack of vancomycin staining for Gram-negative bacteria such as P. aeruginosa and Escherichia coli [70].

To understand the potential of vanc- $800 \mathrm{CW}$ in vivo model, the authors selected a mouse model of myositis induced by bioluminescent $S$. aureus. The administration of vanc$800 \mathrm{CW}$ allows for distinguishing between $S$. aureus-induced infection from E. coli inducedinfection and sterile inflammation. The biodistribution profile also shows similarities with what is described for "native" vancomycin. A complementary post-mortem with contaminated implants was also performed to ensure the feasibility of BAI detection. The results were promising and confirmed the ability of vanc-88CW to stain Staphylococcus epidermis-containing implants. The fluorescent conjugated developed by Marleen van Osteen and colleagues displayed important and crucial results in biofilm imaging [70].

The application of carbon nanotube probes is another promising tool for in vivo targeting and fluorescence optical imaging of bacterial infections [71]. Using genetically engineered M13 virus as a multifunctional vector, Bardhan et al. synthesized NIR-II fluorescent SWNT probes, with additional functionalization on the virus for active targeting of bacterial infections [71]. The authors were able to successfully preform the detection of deep-tissue infective endocarditis using the SWNT probe.

Both works [70,71] contributed positively to the challenge in the field of biomaterialassociated infection diagnostics and for non-invasive detection and monitoring of infectious diseases in the body.

\subsection{Biofilm Detection with iTRAQ (Isobaric Tags for Relative and Absolute Quantitation)-Based Quantitative Proteomics Methods}

As explained before, the biofilm structure contains several proteins that are important for its stability and maintenance [6]. The proteins present in the biofilm naturally depend not only on the type of pathogen but also on the developmental stage of the biofilm [72]. Therefore, identifying biofilm proteins can be a very useful biofilm detection method. For this purpose, isobaric tags for relative and absolute quantitation (iTRAQ)-based quantitative proteomics technique has been reported in several studies [73]. The iTRAQ technique allows for the identification and quantification of hundreds of proteins in different biological samples in one single experiment. It consists of the relative quantification with mass spectrometry of proteins in complex mixtures. iTRAQ technology uses isobaric reagents to label the primary amines of peptides and proteins [73]. During the iTRAQ process, reagents are reactive with amine groups, marking the sample peptides and maintaining the isobaric balance (sample mass does not change) [73,74]. An analysis of the reporter groups that are generated upon fragmentation in the mass spectrometer is then carried out. This procedure is commonly used to distinguish between normal and "diseased" samples and was also used to identify bacterial biofilm proteins [75,76]. Recently, an iTRAQ-based quantitative proteomics approach was used to identify protein markers associated with the biofilm formation of Enterococcus faecalis [77]. In this case, it was observed by iTRAQ that strong biofilm-forming clinical isolates have proteins associated with shikimate kinase pathway and sulfate transport upregulated. This is a relevant information since it can lead to the development of therapies that can act on these metabolic pathways, and consequently inhibit the biofilm formation of Enterococcus faecalis [77]. The iTRAQ technique has also been used to identify proteins present in biofilms that promote caries and other dental problems [78,79]. iTRAQ reporters determined that biofilm cells of Tannerella forsythia have upregulated oxidative stress response proteins, which is related with the fact that this sub-gingival pathogen is more resistant to oxidative stress, thus allowing it to persist in the oral cavity [79]. Thus, the iTRAQ-based quantitative proteomics technique can be 
very useful for biofilm detection and to find possible targets that could lead to biofilm eradication, as it allows for the understanding of which proteins and metabolic pathways are important for biofilm formation.

\subsection{The Use of Artificial Intelligence (AI) Technology for Biofilm Detection}

Machine learning, together with image processing, has been employed in recent years to assist doctors during clinical and diagnostic process [80,81].

For biofilm detection, the use of machine learning models was already reported, e.g., detection of E. coli biofilm using an electro-chemical impedance spectroscopy (EIS)based biosensor [82]. Machine learning systems, for instance, can be trained to recognize multiple impedimetric parameters and determine bacteria concentration. The conjugation of machine learning systems with EIS already showed promising results, even with thicker biofilm [82].

Convolutional neural network (CNN) has already been reported as a successful deep learning model for improving diagnostic field [83]. The CNN model is trained to learn visual patterns from images and has been used for medical images recognition [84,85]. Recently, this model was tested to improve a rhinocytology diagnostic exam [81,86]. For instance, it allowed for the detection of the presence of biofilm on rhino-cytological scans. The sample was stained, and cyan-colored spots were observed and were directly related with biofilm infection [86]. The cyan spots can vary with stage/maturity of the biofilm, and the CNN model system can be trained to recognize these patterns. The CNN model was also applied for detection of biofilm formation (all four stages) attached onto a metallic material. To achieve this purpose, the researchers trained the system to recognize the main features of the process on the basis of microscopy features. For E. coli strain, this mathematical model showed results in accordance with experimental detection of metal biofilm [87].

Moreover, the CNN deep learning model can also be trained to detect polymicrobial biofilm. Antoine Buetti-Dinh et al. reported a CNN model trained to detect a biofilm composed by $A$. caldus strain, L. ferriphilum strain, and $S$. thermosulfi-dooxidans of sulfide minerals. When compared to human experts, the CNN model showed a $90 \%$ of accuracy in contrast with $50 \%$, thus offering an accurate alternative to classical and time-consuming biochemical methods [83].

\section{Antibacterial and Antibiofilm Strategies}

The difficulty of treating bacterial biofilm-associated infections, as explained above, is highly associated with the recalcitrant character of bacterial biofilm and the development of resistance toward antibiotics. Therefore, the development of strategies that allow for efficient inhibition of biofilm formation and/or to completely eradicate biofilms is one of the most challenging research topics of the present day. Understanding the mechanism behind biofilm formation is crucial to developing potential control strategies. This includes exploring potential targets against c-di-GMP, extracellular polysaccharide and eDNA present in biofilm matrix, and bacterial cell membrane and biofilm quorum sensing. In addition, ribonucleases and small non-coding RNAs (sRNAs) can also in the future be considered as potential targets since several research papers were able to demonstrate their importance in biofilm formation and regulation (e.g., [88]). In fact, ribonucleases were found to affect biofilm formation in several bacteria, such as E. coli, Salmonella Typhimurium, P. aeruginosa, and Bacillus subtilis [88-91]. These RNA-degrading enzymes affect biofilms by controlling the expression of biofilm matrix genes but also by modulating the levels of c-di-GMP and other biofilm regulators [92-94]. Other RNA regulators, namely, sRNAs, have been found to have a very important role in biofilm formation and antibiotic resistance [95,96]. However, thus far, no therapeutic drugs target these biofilm regulators, mainly due to the lack of basic knowledge on how exactly ribonucleases and sRNAs could be used to disrupt biofilms.

In the context of therapeutic drugs, several compounds are currently being screened, including the antibody MEDI4893 and the antimicrobial peptide POL7080, both in clinical 
trial phase 2 [97]. Furthermore, in silico analysis or machine learning methods are becoming attractive strategies to help identify potential antibacterial and anti-biofilm inhibitory molecules [98-100]. In recent years, computational methods have emerged following the need for less consuming and more accurate results for the identification of antimicrobial and anti-biofilm molecules. In this context, some computational databases such as biofilm-active AMPs (BaAMPs) and tools/platforms including aBiofilm and Molib were created [101-104]. The aBiofilm platform has already provided the prediction of antimicrobial chemical molecules and their inhibitory activity [103]. Meanwhile, Molib tool, which is a training dataset of biofilm inhibitory molecules, has been shown to be even more accurate than the aBiofilm tool [104]. This focus on discovering small molecules with artificial intelligence might offer future solutions for the search of effective anti-biofilm drug discovery.

In this section, we included examples of several other strategies and compounds that were developed in last years as potential antibacterial and anti-biofilm strategies (see also Figure 2).

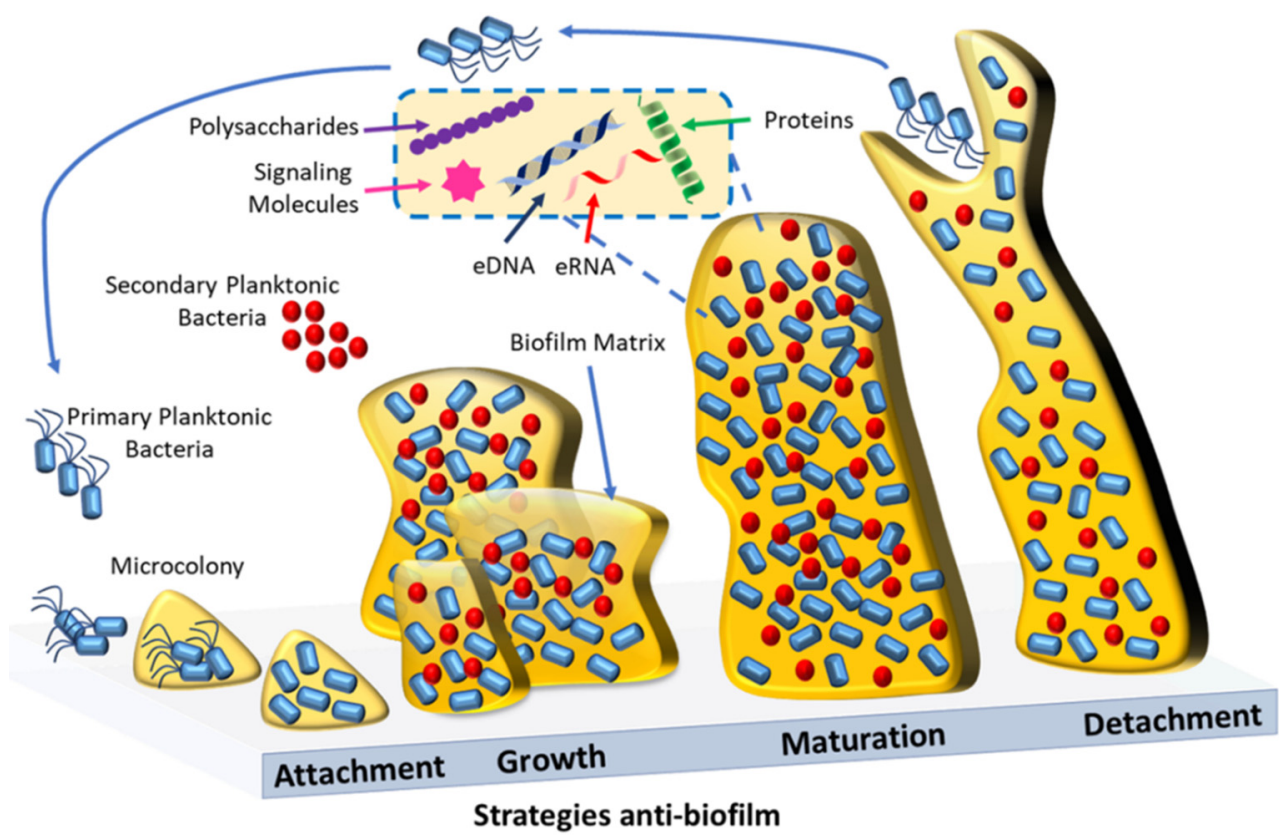

1) Direct bacterial killing

2) QS: signalling molecules target; action anti-earlier biofilm constituents
3) Anti-biofilm matrix agents; dispersing agents

Figure 2. Schematic representation of biofilm formation and the current antibiofilm strategies. Biofilm formation starts with the initial reversible attachment of bacterial cells to a surface, then follows the growth of the biofilm within a matrix; maturation of the biofilm; and finally, when the environment conditions cease to be ideal, the reversal of the attachment with the dispersion of the cells that will colonize other superficies. Antibiofilm agents are capable of inhibiting the biofilm formation by bacteriostatic effects (1), e.g., antimicrobial polymers, or by acting against important early biofilm constituents (2), e.g., quorum sensing inhibitors. Mature biofilm can be disrupted by direct action against the biofilm matrix (3), e.g., biofilm matrix-degrading enzymes. Alternatively mature biofilms can be perturbed by the use of dispersing agents (3), e.g., nitric oxide.

\subsection{Linear and Cationic Polymers/Oligomers}

Antimicrobial polymers have been shown to be promising alternatives to combat microorganisms $[105,106]$. In particular, cationic polymers have been widely explored and shown to be highly efficient in killing both Gram-positive and Gram-negative bacteria [105,107]. To achieve the best performance as antimicrobial agents, researchers have studied multiple polymers and developed them as mimic of antimicrobial peptides (AMP) but with a less expensive cost of production. 
The synthesis of polymers often considers molecular weight, cationic core, hydrophobicity, and architecture. The easily modification and structure optimization allows polymers to respond more accurately to bacterial target/metabolism characteristics. Molecular weight might influence diffusion of polymers across lipid membrane and contribute to bacterial cell death. To mimic AMP mechanism, the synthesis of polymers often includes a cationic group to interact with negative membrane of bacterial cells [106,108-110]. Quaternary ammonium groups or quaternary phosphonium group has been explored as a cationic core in new synthetic polymers [110]. Moreover, hydrophobicity is another important feature in new synthetized polymers to allow the polymers to cross the bacterial membrane.

Madson and co-workers compared star-polymers and linear polymers [111]. The advantage of linear polymers is the feasibly and less complex synthesis. The authors synthetized polymers with (3- acrylamidopropyl)trimethylammonium chloride (AMPTMA), thus having a cationic and hydrophilic segment. To balance hydrophilic/hydrophobic profile, researchers chose n-butyl acrylate (n-BA) as the hydrophobic domain. In this work, the authors showed the potential of linear polymers as potent antimicrobial molecules and demonstrated them to be equally efficient as star-polymer [111]. This illustrated the fact that the polymer architecture itself is not always a requirement to improve antimicrobial activity. In all cases, cationic and hydrophobic groups of synthetic polymers were revealed to be determinant for the polymer's antimicrobial activity.

The antimicrobial potential of linear polymers or oligomers as AMP mimics was clearly demonstrated in several distinct works. For instance, against $E$. coli, linear polyethylemine (L-PEI) presents a minimum inhibitory concentration (MIC) value lower than branched PEI. For E. coli and S. aureus, L-PEI was shown to be able to permeabilize and disrupt bacterial cell membrane. In addition, the authors concluded that cationic and amphiphilic (hydrophobic and hydrophilic balance) are, as expected, crucial for antibacterial activity [112] The potential of oxazoline-based antimicrobial oligomers was explored in two distinct works $[105,106]$. Using supercritical $\mathrm{CO}_{2}$, a method that reduces the use of toxic reagents, Correia et al. obtained biocompatible oxazoline-based oligomers quaternized with different amines [105]. The oxazoline-based oligomers showed a promising antimicrobial activity, and in particular, linear oligoethyleneimine hydrochloride (L-OEI-h) was able to kill several Gram-negative bacteria within a possible therapeutic range $[105,106]$. However, L-OEI-h was not very efficient in killing clinical isolates of Klebsiella pneumoniae producing KPC or OXA-48-like carbapenems [106]. This was attributed to the fact that the capsule of K. pneumonia, which is more "robust" than what was verified for other Gram-negative bacteria, may cause an efficient barrier against several antimicrobial agents, possibly including L-OEI-h. Thus, optimization of polymer design and synthesis can be crucial for eradication of infections caused by multidrug-resistant (MDR) bacteria, and this includes exploring different targets including biofilm quorum sensing. Linear polymers were already shown to target QS. For instance, Cavaleiro et al. described the synthesis of new linear polymers with methyl methacrylate as backbone and itaconic acid and methacrylic acid as monomers [113]. The authors found out that these compounds may interfere with bacteria quorum sensing. The results obtained in this study showed that these polymers decrease Vibrio fisheri bioluminescence, which is a process regulated by QS in this bacterium. The polymers were also efficient in inhibiting biofilm growth of Aeromonas hydrophila [113].

However, this approach directed against QS leads only to the dissociation of the biofilm architecture but not to the eradication of the biofilm. To ensure the total disruption of the biofilm is necessary to implement an additional treatment. This includes combination of several antimicrobial agents (e.g., antibiotics, membrane-lytic compounds such as AMP and cationic polymers) with anti-quorum sensing molecules.

\subsection{Nanoparticles}

Nanosized materials and nanoparticles in particular can play an important alternative to currently used antimicrobial agents or to be used as co-adjuvants. 
Nanoparticles including metallic nanoparticles, liposomes, and dendrimers appeared in response to the lack of antibiotics efficacy and drug resistance. These nanomaterials are very versatile, showing, for instance, the ability for encapsulation of antibiotics $[114,115]$ and other antimicrobial agents. For example, it was recently demonstrated that the encapsulation of an antimicrobial glycolipid biosurfactant with the use of chitosan-based nanoparticles was effective against Helicobacter pylori biofilm [116]. When the use of nanoparticles (NPs) as effective antimicrobial agents is considered, some key properties are also taken into account, such as their large surface area relative to a small size volume and their excellent predisposition for surface modifications. The development of nanotechnology for antimicrobial propose is widely investigated at the pre-clinical level, and some nanoparticles are already approved by the FDA for clinical use (as in the case of liposomal formulations and lipid-based vaccines) or are in clinical trials [114].

As shown in several studies, nanoscale size allows for the nanoparticles to penetrate microbial cell walls and biofilms layers, causing several events such as irreversible damage of microbial membranes $[9,117,118]$. Several hypotheses for nanoparticles mechanisms of action have been explored, including cell membrane alterations and disruption $[119,120]$, ROS generation, and lipid peroxidation [121-123]. Metabolic pathway disruption is also described as a mechanism of NPs [124,125].

As a good example of nanotherapeutics against biofilms, it is the application of polyoxometalates (POMs) supported by gold nanoparticles (AuNPs) on P. aeruginosa and Staphylococcus biofilms, which have been shown to have a potent effect in the inhibition of biofilms. This was attributed to the fact that AuNPs can induce a disruption of cell membrane integrity, leading to bacterial cell death [126].

In addition, NPs are also able to disturb the biofilm integrity by interacting with EPS, eDNA, proteins, and lipids of biofilms [118].

Polymer nanoparticles are the most successful nanoparticles used as antibacterial and antibiofilm strategies. For instance, nanostructures prepared from polymerization of monomers or from polymers were shown to represent a promising approach to overcome biofilm resistance through a controlled drug release strategy [115]. Relevant to this, it was concluded that in $P$. aeruginosa biofilm positively charged peripheral groups accumulate more efficiently into the biofilms [127], which is important information in terms of the design of drug-released nanoparticles, especially considering the presence of negatively charged molecules in the biofilm matrix.

In a different approach, it was shown that cationic nano-engineered dendrimers were able to efficiently eliminate Gram-negative multi-drug-resistant bacteria both in vitro and in vivo systems, with very low toxicity towards human cells [128], and this was achieved without any resistance acquisition by MDR Gram-negative bacteria against their structurally nanoengineered dendrimers.

On the basis of the role of galactose-specific lectin LecA (PA-IL) and the fucose-specific lectin LecB (PA-IIL) on biofilm formation and the effect of deletion of lecA or lecB in biofilm formation, researchers put forward glycopeptide dendrimers as potential inhibitors of lectins LecA and LecB genes $[129,130]$. These dendrimers were evaluated by bioinformatic tools against $P$. aeruginosa biofilms. The results obtained highlight the importance of bioinformatics in this field.

Metal-based nanoparticles also play an important role as an alternative against bacteria and antibiotic resistance. In fact, in the last few years, conventional metallic and biogenic nanostructures have received more attention as innovative antimicrobial agents, and, importantly, metal nanoparticles have an advantage in that they do not differentiate between resistant and susceptible bacteria [131]. The efficacy of simple and composite metal-based nanoparticles against planktonic and biofilm embedded bacteria have been discussed in several publications, including [132]. For instance, silver nanoparticles were shown to induce alterations in bacterial cell membranes, bacterial respiration, metabolism, and proliferation [133]. In addition, in P. aeruginosa biofilms, silver nanoparticles were able to inhibit quorum sensing signaling [134]. Oxide zinc nanoparticles (ZnO NPs) are also 
described to be potent weapons against biofilms [135], since they affect the stability of bacterial cell membrane, leading to bacterial death.

The antibiofilm potential of other metal-based nanoparticles as titanium dioxide NPs was also demonstrated [136]. Titanium-based nanomaterials have shown antibacterial activity against Streptococcus mitis and S. aureus [137], guided by initial electrostatic attraction and rapid killing of the microorganisms that indicates that the coating of medical surfaces with $\mathrm{TiO}_{2} \mathrm{NPs}$ could prevent biofilm formation and reduce the contamination.

In addition, NPs also were described as antimicrobial coating agents with a potential clinical use in wound-dressing, catheters, bone cements, and cardiovascular implants [138].

\subsection{Antibiofilm Photodynamic Therapy (PDT)}

Photodynamic therapy (PDT) emerged recently in the field as an alternative therapy against biofilms [139-141]. PDT is based on employing a photosensitizer-a molecule/ compound that produces cytotoxic ROS species after illumination with a specific wavelength light. The boost in ROS concentration has already shown a lethal effect in microbial pathogens. The main advantage of PDT against biofilms is the dual selectivity characteristic: a photosensitizer specially designed for infections and the adjustment of light wavelength to the lesion area [142].

In addition to the above, nanotechnology has been successfully used to improve the photosensitizer performance. This is the case of mesoporous silica nanoparticles (MSNs) (polymer-based nanoparticles), which were developed to be used as photosensitizer carrier. The malachite green was loaded into MSNs particles, and the efficacy of this nanoplatform was evaluated on Gram-positive and Gram-negative bacteria [143].

\subsection{Nitric Oxide as an Agent against Biofilms}

Nitric oxide (NO) is already reported as a signaling molecule involved in biofilm regulation, being also capable of participating in the regulation of cyclic di-GMP expression by the binding to H-NOX domains (heme-nitric oxide/oxygen-binding) [144,145]. At low concentrations, $\mathrm{NO}$ can make sessile microbes present in biofilm to initiate a motile life phase and consequently promote biofilm dispersion/disaggregation [145-147]. This approach involves NO donors that release $\mathrm{NO}$ and induce biofilm disruption. NO donors can be applied in different ways: as small molecules, incorporated into a polymeric delivery agent, or attached to a surface of polymeric or non-polymeric structure [148,149].

Despite the success of NO donors (e.g., SNP), there are some drawbacks already identified with this strategy, including the fact that the decomposition of some NO donors can release cyanide. In this sense, some alternatives to NO donors were explored, including the nitroxides. These are small molecules that possess a stabilized free radical and identical electronic properties to NO. Nitroxides can have an impact in biofilm growth but are not enough to kill bacteria directly. To overcome this issue, these compounds have already been used in combination with antibiotics for improvement of biofilm treatment and total eradication [150,151].

The potential of nitroxides on surface coating to prevent biofilm formation was also explored. For this, it was demonstrated that the use of polynitroxides, as a source of nitroxide, allow for the reduction of biofilm formation. In P. aeruginosa biofilm, the polynitroxide coating reduced the number of bacteria by up to $99 \%$, an effect that was reported to be independent of concentration [152].

\subsection{Biofilm Matrix-Degrading Enzymes}

Biofilm matrix is composed of distinct elements including polysaccharides, proteins, and nucleic acids (eDNA and RNA) [153]. Several relevant functions are attributed to this biofilm structure, such as being a first line of defense against antimicrobial treatments [8]. Thus, many actual anti-biofilm strategies are designed to target the biofilm matrix and/or its components. This is the case of treatments that use biofilm-degrading enzymes. For instance, dispersin B, produced by the periodontal pathogen Aggregatibacter actinomycetem- 
comitans, was able to disintegrate mature staphylococcal biofilms. The enzyme acts by hydrolyzing the glycosidic linkages in the polysaccharide present in the staphylococcal biofilm matrix [154]. The effects of other enzymes are also reported for distinct biofilms. For instance, alginate lyase has been frequently used against the alginate polymer present in the P. aeruginosa biofilm matrix [155].

Some reports also showed that combined therapeutics results are an improvement in the anti-biofilm therapeutics. For instance, combination of DNase I (that denatures the eDNA) and dispersin B was found to inhibit staphylococcal skin colonization in an in vivo model [156]. Other studies were able to demonstrate the efficacy of combining biofilmdegrading enzymes with antimicrobial agents [157-159]. This is the case of meropenem and amikacin antibiotics that were combined with a trypsin/DNase I mixture against $S$. aureus-P. aeruginosa dual strain biofilms. The minimal biofilm eradication concentration (MBECs) values of both antibiotics were shown to decrease significantly when combined with the enzyme mixture [159].

Although being recognized as a potential relevant treatment in the fight against biofilms, the use of enzymes that degrade biofilm matrix is still very limited due to problems such as high cost associated with their production, handling procedures, and difficult largescale production [159].

\subsection{Targeting Amyloid-like Fibers}

For years, amyloid fibers were only associated with progressive human disorders including Alzheimer's disease and type II diabetes. However, currently, they are recognized to play important biological roles in biofilm formation, thus being called in this case functional amyloid fibers [160]. When these amyloid-like fibers are correlated with the biofilm matrix, they can contribute to cell-cell and cell-surface interactions [161]. Moreover, in bacteria, the functional amyloid fibers can act as a protection barrier [162] or interfere with the function of specific proteins. In this sense, amyloid-like fibers represent interesting targets for the development of antibacterial and anti-biofilm drugs [163,164].

B. subtilis extracellular matrix contains two major components, an exopolysaccharide and the amyloid-like fibers formed by the TasA protein [165]. Thus, targeting TasA protein was demonstrated to be a possible alternative to conventional treatments [163]. The AA-861 and parthenolide compounds were shown to efficiently inhibit the formation of $B$. subtilis biofilms by inhibiting polymerization of the amyloid-like fibers of TasA [163], which reveals the importance of this amyloid-like fiber for the maturation of $B$. subtilis biofilms. Additionally, AA-861 and parthenolide were shown to have anti-biofilm activity against E. coli. The anti-biofilm mechanism was correlated with the inhibition of polymerization of Curli (the amyloid-like fiber present in E. coli biofilms) [163].

\subsection{Targeting Functional Membrane Microdomains (FMM)}

In the last decade, it was discovered that bacteria organize signal transduction, protein secretion, and transport processes in functional membrane microdomains (FMM), both in Gram-positive and Gram-negative cells [166]. This suggests that membrane organization and signaling transduction in bacteria is much more sophisticated than initially considered. Membrane domains in bacteria exhibit considerable heterogeneity, as evidenced by the detection of regions of increased fluidity (RIF). Curvature also regulates protein compartmentalization in bacterial membranes, as DivIVA and SpoVM have been, respectively, shown to display accumulation in sites of high negative (septation sites or poles) and positive membrane curvature (forespore membrane).

Considering the above, the FMMs are an attractive target to antibacterial agents [167].

Membrane domains with higher order were revealed in wild-type B. subtilis, and these were disrupted through the inhibition of polyisoprenoid lipid synthesis, suggesting that cyclic and noncyclic polyisoprenoids are likely to contribute to FMM formation. Inhibition of polyisoprenoid lipid synthesis also prevented biofilm synthesis in B. subtilis and S. aureus, revealing a possible link between these processes and FMM [167,168]. 
In B. subtilis, two different flotillin-like proteins, FloA and FloT, were found to insert in ordered FMM domains. Both of these proteins exhibit a punctate distribution dependent on polyisoprenoid lipids and cardiolipin (CL) [168]. FloA and FLoT were recently proposed to interact with a great number of different proteins, likely regulating their insertion in FMMs. Mutants lacking flotillins show severe dysfunction of diverse physiological processes, such as biofilm formation, natural competence, or sporulation $[169,170]$.

\subsection{Combination of Diagnosis and Treatment}

The early detection of bacterial infections and tracing the issue of drug resistance with more efficient treatment are essential requisites to fight bacterial biofilms. In this sense, an interesting strategy for the selective treatment on the basis of drug resistance was recently proposed [171]. Paper-based devices (PBD) are promising platforms for antibacterial therapy. This methodology offers a sustainable, biosafety and low-cost alternative in the field of bacterial infections [172,173]. Furthermore, portable paper-based band-aids (PBA) were developed for sensing and treating drug resistance. A paper-based strategy was produced for drug-resistant bacteria, and it can test for the presence of $\beta$-lactamasemediated resistance combined with selective antibacterial treatment after sensing drug resistance [171]. For detection of drug resistance, a colorimetric method can also be used [174]. In this case, drug-sensitive bacteria (DS) were detected by a color change from green to yellow. Then ampicillin-loaded nanomaterials (coated with chitosan) were able to eradicate DS bacteria. For drug-resistant (DR) bacteria, the colorimetric substrate nitrocefin can also be used. By the action of $\beta$-lactamase, which is secreted by many resistant bacteria, the subtract changed color from yellow to red. To treat drug-resistant bacteria, the authors developed porphyrin-based metal-organic frameworks (MOFs) that produce ROS after irradiation with light decreasing resistance to antibiotics [171]. The above elements were integrated together into cellulose paper, and the proof of concept was validated on DS and DR strains of E. coli.

\section{Conclusions}

Bacterial infection remains a challenge as result of the increasing number of antimicrobialresistant strains. Consequently, bacterial infections are still responsible for high rates of mortality around the globe. This is in part due to the fact that a successful treatment is extremely hard to achieve once matured biofilms are established. They correspond to complex structures that can give bacteria strong hypothesis to survive, even under stress conditions (e.g., low amount of nutrients, low $\mathrm{O}_{2}$ levels, and acidic $\mathrm{pH}$ ). Due to their structure, biofilms are difficult to study, and in this report, we have reviewed the state-of-the-art imaging techniques that are currently in use to study biofilms. We believe that an early detection of biofilms will be certainly helpful to treat patients and reduce healthcare costs. This can only happen through a continued improvement of the detection techniques and methodologies.

Furthermore, we explored several antibacterial and antibiofilm strategies (summarized in Table 1) that are being developed and that can only advance with the expansion of our scientific knowledge.

Table 1. Antibacterial and antibiofilm strategies and their mechanism of action.

\begin{tabular}{|c|c|c|}
\hline $\begin{array}{l}\text { Antibacterial and Anti-Biofilm } \\
\text { Strategies }\end{array}$ & Compounds & Mechanism of Action \\
\hline \multirow{3}{*}{$\begin{array}{l}\text { Linear and cationic polymers / } \\
\text { oligomers }\end{array}$} & $\begin{array}{l}\text { Oxazoline-based antimicrobial oligomers } \\
\text { (e.g., L-OEI-h) }\end{array}$ & $\begin{array}{l}\text { Permeabilize and disrupt bacterial } \\
\text { cell membrane. }\end{array}$ \\
\hline & Linear polyethylemine (L-PEI) & $\begin{array}{l}\text { Permeabilize and disrupt bacterial cell } \\
\text { membrane. }\end{array}$ \\
\hline & $\begin{array}{l}\text { Linear polymers with methyl } \\
\text { methacrylate as backbone, and itaconic } \\
\text { acid and methacrylic acid as monomers }\end{array}$ & $\begin{array}{l}\text { Interfere with QS systems, needs to be } \\
\text { complemented with another } \\
\text { antimicrobial agent. }\end{array}$ \\
\hline
\end{tabular}


Table 1. Cont.

\begin{tabular}{|c|c|c|}
\hline $\begin{array}{c}\text { Antibacterial and Anti-Biofilm } \\
\text { Strategies }\end{array}$ & Compounds & Mechanism of Action \\
\hline \multirow{6}{*}{ Nanoparticles } & $\begin{array}{l}\text { Polyoxometalates (POMs) supported by } \\
\text { gold nanoparticles (AuNPs) }\end{array}$ & Disrupt cell membrane integrity. \\
\hline & Polymer nanoparticles & Efficient in disrupting biofilm matrix. \\
\hline & Glycopeptide dendrimers & $\begin{array}{l}\text { Potential inhibitors of lectins LecA and } \\
\text { LecB genes. }\end{array}$ \\
\hline & Silver nanoparticles & $\begin{array}{c}\text { Induce alterations in bacterial cell } \\
\text { membranes, bacterial respiration, } \\
\text { metabolism, and proliferation. Moreover, } \\
\text { inhibits QS signaling. }\end{array}$ \\
\hline & Oxide zinc nanoparticles & $\begin{array}{l}\text { Affect the stability of bacterial cell } \\
\text { membrane. }\end{array}$ \\
\hline & Titanium dioxide nanoparticles & $\begin{array}{l}\text { Antibacterial and anti-biofilm proprieties } \\
\text { guided by initial electrostatic attraction. }\end{array}$ \\
\hline Photodynamic therapy (PDT) & $\begin{array}{c}\text { Photosensitizer-a molecule/compound } \\
\text { that produces cytotoxic ROS species after } \\
\text { illumination with a specific } \\
\text { wavelength light }\end{array}$ & $\begin{array}{c}\text { ROS concentration increase leads to } \\
\text { bacterial death. }\end{array}$ \\
\hline Nitric oxide & Nitroxides & $\begin{array}{c}\text { Affects biofilms but not sufficient to kill } \\
\text { bacteria. }\end{array}$ \\
\hline \multirow{2}{*}{ Biofilm matrix-degrading enzymes } & Dispersin B & $\begin{array}{l}\text { Hydrolyzes the glycosidic linkages in the } \\
\text { polysaccharide present in the biofilm matrix. }\end{array}$ \\
\hline & $\begin{array}{l}\text { Alginate lyase } \\
\text { DNase I }\end{array}$ & $\begin{array}{l}\text { Lyses alginate from the biofilm matrix. } \\
\text { Denatures eDNA. }\end{array}$ \\
\hline Targeting amyloid-like fibers & AA-861 and parthenolide & $\begin{array}{l}\text { Inhibit polymerization of the amyloid-like } \\
\text { fibers of TasA and Curli. }\end{array}$ \\
\hline $\begin{array}{l}\text { Targeting functional membrane } \\
\text { microdomains (FMM) }\end{array}$ & FloA and FloT & $\begin{array}{l}\text { Regulate the insertion of other proteins } \\
\text { in FMMs. }\end{array}$ \\
\hline
\end{tabular}

Author Contributions: Conceptualization-V.P., S.N.P.; writing-review and editing, A.C., M.C., B.C., C.M.A., V.P., S.N.P.; supervision-V.P., S.N.P. All authors have read and agreed to the published version of the manuscript.

Funding: This work is financed by national funds from FCT-Fundação para a Ciência e a Tecnologia, I.P., in the scope of the project UIDB/04565/2020 and UIDP/04565/2020 of the Research Unit Institute for Bioengineering and Biosciences-iBB, project LA/P/0140/2020 of the Associate Laboratory Institute for Health and Bioeconomy-i4HB, I.P. and the project MOSTMICRO-ITQB with refs UIDB/04612/2020 and UIDP/04612/2020. M.C. and A.C. are the recipients of FCT PhD fellowships (PD/BD/150602/2020 and DFA/BD/5203/2020, respectively). V.P. and S.N.P. are financed by an FCT contract according to DL57/2016 (SFRH/BPD/92409/2013 and SFRH/BPD/87188/2012, respectively).

Data Availability Statement: Not applicable.

Acknowledgments: We thank Marta M. Alves (CQE, Departamento de Engenharia Química, Instituto Superior Técnico, Universidade de Lisboa) for the acquisition of MRSA biofilm SEM image.

Conflicts of Interest: The authors declare no conflict of interest.

\section{References}

1. Ventola, C.L. The antibiotic resistance crisis: Part 1: Causes and threats. Pharm. Therapeutics 2015, 40, $277-283$.

2. O'Neill, J. Review on Antimicrobial Resistance. December 2014. Available online: http://amr-review.org/ (accessed on 15 September 2021).

3. Carmen, J.C.; Roeder, B.L.; Nelson, J.L.; Ogilvie, R.L.R.; Robison, R.A.; Schaalje, G.B.; Pitt, W.G. Treatment of biofilm infections on implants with low-frequency ultrasound and antibiotics. Am. J. Infect. Control. 2005, 33, 78-82. [CrossRef]

4. Römling, U.; Balsalobre, C. Biofilm infections, their resilience to therapy and innovative treatment strategies. J. Intern. Med. 2012, 272, 541-561. [CrossRef] 
5. Malik, A.; Mohammad, Z.; Ahmad, J. The diabetic foot infections: Biofilms and antimicrobial resistance. Diabetes Metab. Syndr. 2013, 7, 101-107. [CrossRef] [PubMed]

6. O'Toole, G.; Kaplan, H.B.; Kolter, R. Biofilm formation as microbial development. Annu. Rev. Microbiol. 2000, 54, 49-79. [CrossRef]

7. Wu, H.; Moser, C.; Wang, H.Z.; Høiby, N.; Song, Z.J. Strategies for combating bacterial biofilm infections. Int. J. Oral Sci. 2015, 7, 1-7. [CrossRef]

8. Pinto, S.N.; Dias, S.A.; Cruz, A.F.; Mil-Homens, D.; Fernandes, F.; Valle, J.; Andreu, D.; Prieto, M.; Castanho, M.; Coutinho, A.; et al The mechanism of action of pepR, a viral-derived peptide, against Staphylococcus aureus biofilms. J. Antimicrob. Chemother. 2019, 74, 2617-2625. [CrossRef]

9. Ferreira, M.; Pinto, S.N.; Aires-da-Silva, F.; Bettencourt, A.; Aguiar, S.I.; Gaspar, M.M. Liposomes as a Nanoplatform to Improve the Delivery of Antibiotics into Staphylococcus aureus Biofilms. Pharmaceutics 2021, 13, 321. [CrossRef]

10. Jefferson, K.K.; Goldmann, D.A.; Pier, G.B. Use of confocal microscopy to analyze the rate of vancomycin penetration through Staphylococcus aureus biofilms. Antimicrob. Agents Chemother. 2005, 49, 2467-2473. [CrossRef] [PubMed]

11. Mah, T.F.; O'Toole, G.A. Mechanisms of biofilm resistance to antimicrobial agents. Trends Microbiol. 2001, 9, 34-39. [CrossRef]

12. Whiteley, M.; Diggle, S.P.; Greenberg, E.P. Progress in and promise of bacterial quorum sensing research. Nature 2017, 551, 313-320. [CrossRef]

13. Paluch, E.; Rewak-Soroczyńska, J.; Jędrusik, I.; Mazurkiewicz, E.; Jermakow, K. Prevention of biofilm formation by quorum quenching. Appl. Microbiol. Biotechnol. 2020, 104, 1871-1881. [CrossRef] [PubMed]

14. Salmanoglu, E.; Kim, S.; Thakur, M.L. Currently Available Radiopharmaceuticals for Imaging Infection and the Holy Grail. Semin. Nucl. Med. 2018, 48, 86-99. [CrossRef]

15. Israel, O.; Keidar, Z. PET/CT imaging in infectious conditions. Ann. N. Y. Acad. Sci. 2011, 1228, 150-166. [CrossRef]

16. Eggleston, H.; Panizzi, P. Molecular imaging of bacterial infections in vivo: The discrimination of infection from inflammation. Informatics 2014, 1, 72-99. [CrossRef]

17. Ning, X.; Seo, W.; Lee, S.; Takemiya, K.; Rafi, M.; Feng, X.; Weiss, D.; Wang, X.; Williams, L.; Camp, V.M.; et al. PET imaging of bacterial infections with fluorine-18-labeled maltohexaose. Angew. Chem. Int. Ed. Engl. 2014, 53, 14096-14101. [CrossRef]

18. Auletta, S.; Varani, M.; Horvat, R.; Galli, F.; Signore, A.; Hess, S. PET Radiopharmaceuticals for Specific Bacteria Imaging: A Systematic Review. J. Clin. Med. 2019, 8, 197. [CrossRef] [PubMed]

19. Glaudemans, A.W.; Signore, A. FDG-PET/CT in infections: The imaging method of choice? Eur. J. Nucl. Med. Mol. Imaging 2010, 37, 1986-1991. [CrossRef]

20. Erba, P.A.; Bandera, F.; Sollini, M.; Tascini, C. The use of 18F-FDG-PET/CT in the diagnostic workup of CIED infections: Another perspective. J. Am. Coll. Cardiol. 2012, 60, 1435-1436. [CrossRef] [PubMed]

21. Gopal, S.; Berg, D.; Hagen, N.; Schriefer, E.M.; Stoll, R.; Goebel, W.; Kreft, J. Maltose and maltodextrin utilization by Listeria monocytogenes depend on an inducible ABC transporter which is repressed by glucose. PLoS ONE 2010, 5, e10349. [CrossRef] [PubMed]

22. Kujundzic, E.; Fonseca, A.C.; Evans, E.A.; Peterson, M.; Greenberg, A.R.; Hernandez, M. Ultrasonic monitoring of early-stage biofilm growth on polymeric surfaces. J. Microbiol. Methods 2007, 68, 458-467. [CrossRef]

23. Vaidya, K.; Osgood, R.; Ren, D.; Pichichero, M.E.; Helguera, M. Ultrasound imaging and characterization of biofilms based on wavelet de-noised radiofrequency data. Ultrasound Med. Biol. 2014, 40, 583-595. [CrossRef] [PubMed]

24. Calliada, F.; Campani, R.; Bottinelli, O.; Bozzini, A.; Sommaruga, M.G. Ultrasound contrast agents: Basic principles. Eur. J. Radiol. 1998, 27 (Suppl. 2), S157-S160. [CrossRef]

25. Unnikrishnan, S.; Klibanov, A.L. Microbubbles as ultrasound contrast agents for molecular imaging: Preparation and application. AJR Am. J. Roentgenol. 2012, 199, 292-299. [CrossRef]

26. Anastasiadis, P.; Mojica, K.D.; Allen, J.S.; Matter, M.L. Detection and quantification of bacterial biofilms combining high-frequency acoustic microscopy and targeted lipid microparticles. J. Nanobiotechnol. 2014, 12, 24. [CrossRef] [PubMed]

27. Di Domenico, E.G.; Rimoldi, S.G.; Cavallo, I.; D’Agosto, G.; Trento, E.; Cagnoni, G.; Palazzin, A.; Pagani, C.; Romeri, F.; De Vecchi, E.; et al. Microbial biofilm correlates with an increased antibiotic tolerance and poor therapeutic outcome in infective endocarditis. BMC Microbiol. 2019, 19, 228. [CrossRef] [PubMed]

28. Roy, R.; Tiwari, M.; Donelli, G.; Tiwari, V. Strategies for combating bacterial biofilms: A focus on anti-biofilm agents and their mechanisms of action. Virulence 2018, 9, 522-554. [CrossRef] [PubMed]

29. Bossù, M.; Selan, L.; Artini, M.; Relucenti, M.; Familiari, G.; Papa, R.; Vrenna, G.; Spigaglia, P.; Barbanti, F.; Salucci, A.; et al. Characterization of Scardovia wiggsiae Biofilm by Original Scanning Electron Microscopy Protocol. Microorganisms $2020,8,807$. [CrossRef]

30. Asahi, Y.; Miura, J.; Tsuda, T.; Kuwabata, S.; Tsunashima, K.; Noiri, Y.; Sakata, T.; Ebisu, S.; Hayashi, M. Simple observation of Streptococcus mutans biofilm by scanning electron microscopy using ionic liquids. AMB Express 2015, 5, 6. [CrossRef] [PubMed]

31. Gomes, L.C.; Mergulhão, F.J. SEM Analysis of Surface Impact on Biofilm Antibiotic Treatment. Scanning 2017, $2017,2960194$. [CrossRef] [PubMed]

32. Ruan, X.; Deng, X.; Tan, M.; Yu, C.; Zhang, M.; Sun, Y.; Jiang, N. In vitro antibiofilm activity of resveratrol against avian pathogenic Escherichia coli. BMC Vet. Res. 2021, 17, 249. [CrossRef] 
33. Alves, M.M.; Bouchami, O.; Tavares, A.; Córdoba, L.; Santos, C.F.; Miragaia, M.; de Fátima Montemor, M. New Insights into Antibiofilm Effect of a Nanosized ZnO Coating against the Pathogenic Methicillin Resistant Staphylococcus aureus. ACS Appl. Mater. Interfaces 2017, 9, 28157-28167. [CrossRef]

34. Franklin, M.J.; Chang, C.; Akiyama, T.; Bothner, B. New Technologies for Studying Biofilms. Microbiol. Spectr. 2015, 3, 1-32. [CrossRef] [PubMed]

35. Paddock, S.W. Principles and practices of laser scanning confocal microscopy. Mol. Biotechnol. 2000, 16, 127-149. [CrossRef]

36. Bayguinov, P.O.; Oakley, D.M.; Shih, C.C.; Geanon, D.J.; Joens, M.S.; Fitzpatrick, J.A.J. Modern Laser Scanning Confocal Microscopy. Curr. Protoc. Cytom. 2018, 85, e39. [CrossRef]

37. Neu, T.R.; Swerhone, G.D.W.; Lawrence, J.R. Assessment of lectin-binding analysis for in situ detection of glycoconjugates in biofilm systems. Microbiology 2001, 147, 299-313. [CrossRef] [PubMed]

38. Skogman, M.E.; Vuorela, P.M.; Fallarero, A. Combining biofilm matrix measurements with biomass and viability assays in susceptibility assessments of antimicrobials against Staphylococcus aureus biofilms. J. Antibiot. 2012, 65, 453-459. [CrossRef] [PubMed]

39. Strathmann, M.; Wingender, J.; Flemming, H.C. Application of fluorescently labelled lectins for the visualization and biochemical characterization of polysaccharides in biofilms of Pseudomonas aeruginosa. J. Microbiol. Methods 2002, 50, 237-248. [CrossRef]

40. Okshevsky, M.; Meyer, R.L. Evaluation of fluorescent stains for visualizing extracellular DNA in biofilms. J. Microbiol. Methods 2014, 105, 102-104. [CrossRef]

41. Kwon, H.Y.; Kim, J.Y.; Liu, X.; Lee, J.Y.; Yam, J.K.H.; Dahl Hultqvist, L.; Xu, W.; Rybtke, M.; Tolker-Nielsen, T.; Heo, W.; et al. Visualizing biofilm by targeting eDNA with long wavelength probe CDr15. Biomater. Sci. 2019, 7, 3594-3598. [CrossRef]

42. Kim, J.Y.; Sahu, S.; Yau, Y.H.; Wang, X.; Shochat, S.G.; Nielsen, P.H.; Dueholm, M.S.; Otzen, D.E.; Lee, J.; Delos Santos, M.M.; et al. Detection of Pathogenic Biofilms with Bacterial Amyloid Targeting Fluorescent Probe, CDy11. J. Am. Chem. Soc. 2016, 138, 402-407. [CrossRef] [PubMed]

43. Kwon, H.Y.; Kim, J.Y.; Lee, J.Y.; Yam, J.K.H.; Hultqvist, L.D.; Xu, W.; Rybtke, M.; Tolker-Nielsen, T.; Kim, J.J.; Kang, N.Y.; et al. CDy14: A novel biofilm probe targeting exopolysaccharide Psl. Chem. Commun. 2018, 54, 11865-11868. [CrossRef]

44. Ritenberg, M.; Nandi, S.; Kolusheva, S.; Dandela, R.; Meijler, M.M.; Jelinek, R. Imaging Pseudomonas aeruginosa Biofilm Extracellular Polymer Scaffolds with Amphiphilic Carbon Dots. ACS Chem. Biol. 2016, 11, 1265-1270. [CrossRef]

45. Amann, R.; Fuchs, B.M. Single-cell identification in microbial communities by improved fluorescence in situ hybridization techniques. Nat. Rev. Microbiol. 2008, 6, 339-348. [CrossRef]

46. Daims, H.; Wagner, M. Quantification of uncultured microorganisms by fluorescence microscopy and digital image analysis. Appl. Microbiol. Biotechnol. 2007, 75, 237-248. [CrossRef]

47. Cerqueira, L.; Azevedo, N.F.; Almeida, C.; Jardim, T.; Keevil, C.W.; Vieira, M.J. DNA mimics for the rapid identification of microorganisms by fluorescence in situ hybridization (FISH). Int. J. Mol. Sci. 2008, 9, 1944-1960. [CrossRef]

48. Almeida, C.; Azevedo, N.F.; Santos, S.; Keevil, C.W.; Vieira, M.J. Discriminating multi-species populations in biofilms with peptide nucleic acid fluorescence in situ hybridization (PNA FISH). PLoS ONE 2011, 6, e14786. [CrossRef]

49. Malic, S.; Hill, K.E.; Hayes, A.; Percival, S.L.; Thomas, D.W.; Williams, D.W. Detection and identification of specific bacteria in wound biofilms using peptide nucleic acid fluorescent in situ hybridization (PNA FISH). Microbiology 2009, 155, $2603-2611$. [CrossRef]

50. Cowan, S.E.; Gilbert, E.; Khlebnikov, A.; Keasling, J.D. Dual labeling with green fluorescent proteins for confocal microscopy. Appl. Environ. Microbiol. 2000, 66, 413-418. [CrossRef]

51. Lagendijk, E.L.; Validov, S.; Lamers, G.E.; de Weert, S.; Bloemberg, G.V. Genetic tools for tagging Gram-negative bacteria with mCherry for visualization in vitro and in natural habitats, biofilm and pathogenicity studies. FEMS Microbiol. Lett. 2010, 305, 81-90. [CrossRef] [PubMed]

52. Andersen, J.B.; Heydorn, A.; Hentzer, M.; Eberl, L.; Geisenberger, O.; Christensen, B.B.; Molin, S.; Givskov, M. gfp-based $\mathrm{N}$-acyl homoserine-lactone sensor systems for detection of bacterial communication. Appl. Environ. Microbiol. 2001, 67, 575-585. [CrossRef] [PubMed]

53. Møller, S.; Sternberg, C.; Andersen, J.B.; Christensen, B.B.; Ramos, J.L.; Givskov, M.; Molin, S. In situ gene expression in mixedculture biofilms: Evidence of metabolic interactions between community members. Appl. Environ. Microbiol. 1998, 64, 721-732. [CrossRef]

54. Pamp, S.J.; Gjermansen, M.; Johansen, H.K.; Tolker-Nielsen, T. Tolerance to the antimicrobial peptide colistin in Pseudomonas aeruginosa biofilms is linked to metabolically active cells, and depends on the pmr and mexAB-oprM genes. Mol. Microbiol. 2008, 68, 223-240. [CrossRef] [PubMed]

55. Karampatzakis, A.; Song, C.Z.; Allsopp, L.P.; Filloux, A.; Rice, S.A.; Cohen, Y.; Wohland, T.; Török, P. Probing the internal micromechanical properties of Pseudomonas aeruginosa biofilms by Brillouin imaging. npj Biofilms Microbiomes 2017, 3, 20. [CrossRef] [PubMed]

56. Monmeyran, A.; Thomen, P.; Jonquière, H.; Sureau, F.; Li, C.; Plamont, M.A.; Douarche, C.; Casella, J.F.; Gautier, A.; Henry, N. The inducible chemical-genetic fluorescent marker FAST outperforms classical fluorescent proteins in the quantitative reporting of bacterial biofilm dynamics. Sci. Rep. 2018, 8, 10336. [CrossRef] [PubMed]

57. Benoit, M.R.; Conant, C.G.; Ionescu-Zanetti, C.; Schwartz, M.; Matin, A. New device for high-throughput viability screening of flow biofilms. Appl. Environ. Microbiol. 2010, 76, 4136-4142. [CrossRef] 
58. Straub, H.; Eberl, L.; Zinn, M.; Rossi, R.M.; Maniura-Weber, K.; Ren, Q. A microfluidic platform for in situ investigation of biofilm formation and its treatment under controlled conditions. J. Nanobiotechnol. 2020, 18, 166. [CrossRef] [PubMed]

59. Rojo-Molinero, E.; Macià, M.D.; Oliver, A. Social Behavior of Antibiotic Resistant Mutants Within Pseudomonas aeruginosa Biofilm Communities. Front. Microbiol. 2019, 10, 570. [CrossRef]

60. Boks, N.P.; Norde, W.; van der Mei, H.C.; Busscher, H.J. Forces involved in bacterial adhesion to hydrophilic and hydrophobic surfaces. Microbiology 2008, 154, 3122-3133. [CrossRef] [PubMed]

61. Hansen, M.C.; Palmer, R.J.; Udsen, C.; White, D.C.; Molin, S. Assessment of GFP fluorescence in cells of Streptococcus gordonii under conditions of low $\mathrm{pH}$ and low oxygen concentration. Microbiology 2001, 147, 1383-1391. [CrossRef]

62. Kaur, R.P.; Ludhiadch, A.; Munshi, A. Chapter 9-Single-Cell Genomics: Technology and Applications. In Single-Cell Omics; Barh, D., Azevedo, V., Eds.; Academic Press: Waltham, MA, USA, 2019; pp. 179-197.

63. Alonso, A. DNA Extraction and Quantification. In Encyclopedia of Forensic Sciences, 2nd ed.; Siegel, J.A., Saukko, P.J., Houck, M.M., Eds.; Academic Press: Waltham, MA, USA, 2013; pp. 214-218.

64. Larochelle, S. STOMPing at the bits. Nat. Methods 2015, 12, 1114. [CrossRef] [PubMed]

65. Domazet, B.; Maclennan, G.T.; Lopez-Beltran, A.; Montironi, R.; Cheng, L. Laser capture microdissection in the genomic and proteomic era: Targeting the genetic basis of cancer. Int. J. Clin. Exp. Pathol. 2008, 1, 475-488.

66. Consentino, L.; Rejasse, A.; Crapart, N.; Bevilacqua, C.; Nielsen-LeRoux, C. Laser capture microdissection to study Bacillus cereus iron homeostasis gene expression during Galleria mellonella in vivo gut colonization. Virulence 2021, 12, 2104-2121. [CrossRef] [PubMed]

67. van Dam, G.M.; Themelis, G.; Crane, L.M.; Harlaar, N.J.; Pleijhuis, R.G.; Kelder, W.; Sarantopoulos, A.; de Jong, J.S.; Arts, H.J.; van der Zee, A.G.; et al. Intraoperative tumor-specific fluorescence imaging in ovarian cancer by folate receptor- $\alpha$ targeting: First in-human results. Nat. Med. 2011, 17, 1315-1319. [CrossRef] [PubMed]

68. Kong, Y.; Yao, H.; Ren, H.; Subbian, S.; Cirillo, S.L.; Sacchettini, J.C.; Rao, J.; Cirillo, J.D. Imaging tuberculosis with endogenous beta-lactamase reporter enzyme fluorescence in live mice. Proc. Natl. Acad. Sci. USA 2010, 107, 12239-12244. [CrossRef] [PubMed]

69. Panizzi, P.; Nahrendorf, M.; Figueiredo, J.L.; Panizzi, J.; Marinelli, B.; Iwamoto, Y.; Keliher, E.; Maddur, A.A.; Waterman, P.; Kroh, H.K.; et al. In vivo detection of Staphylococcus aureus endocarditis by targeting pathogen-specific prothrombin activation. Nat. Med. 2011, 17, 1142-1146. [CrossRef] [PubMed]

70. van Oosten, M.; Schäfer, T.; Gazendam, J.A.; Ohlsen, K.; Tsompanidou, E.; de Goffau, M.C.; Harmsen, H.J.; Crane, L.M.; Lim, E.; Francis, K.P.; et al. Real-time in vivo imaging of invasive- and biomaterial-associated bacterial infections using fluorescently labelled vancomycin. Nat. Commun. 2013, 4, 2584. [CrossRef] [PubMed]

71. Bardhan, N.M.; Ghosh, D.; Belcher, A.M. Carbon nanotubes as in vivo bacterial probes. Nat. Commun. 2014, 5, 4918. [CrossRef]

72. Sauer, K. The genomics and proteomics of biofilm formation. Genome Biol. 2003, 4, 219. [CrossRef]

73. Wiese, S.; Reidegeld, K.A.; Meyer, H.E.; Warscheid, B. Protein labeling by iTRAQ: A new tool for quantitative mass spectrometry in proteome research. Proteomics 2007, 7, 340-350. [CrossRef] [PubMed]

74. Hultin-Rosenberg, L.; Forshed, J.; Branca, R.M.; Lehtiö, J.; Johansson, H.J. Defining, comparing, and improving iTRAQ quantification in mass spectrometry proteomics data. Mol. Cell. Proteom. 2013, 12, 2021-2031. [CrossRef]

75. Luczak, M.; Formanowicz, D.; Marczak, Ł.; Suszyńska-Zajczyk, J.; Pawliczak, E.; Wanic-Kossowska, M.; Stobiecki, M. iTRAQbased proteomic analysis of plasma reveals abnormalities in lipid metabolism proteins in chronic kidney disease-related atherosclerosis. Sci. Rep. 2016, 6, 32511. [CrossRef] [PubMed]

76. Trinh, H.V.; Grossmann, J.; Gehrig, P.; Roschitzki, B.; Schlapbach, R.; Greber, U.F.; Hemmi, S. iTRAQ-Based and Label-Free Proteomics Approaches for Studies of Human Adenovirus Infections. Int. J. Proteom. 2013, 2013, 581862. [CrossRef]

77. Suriyanarayanan, T.; Qingsong, L.; Kwang, L.T.; Mun, L.Y.; Truong, T.; Seneviratne, C.J. Quantitative Proteomics of Strong and Weak Biofilm Formers of Enterococcus faecalis Reveals Novel Regulators of Biofilm Formation. Mol. Cell. Proteom. 2018, 17, 643-654. [CrossRef] [PubMed]

78. Wang, K.; Wang, Y.; Wang, X.; Ren, Q.; Han, S.; Ding, L.; Li, Z.; Zhou, X.; Li, W.; Zhang, L. Comparative salivary proteomics analysis of children with and without dental caries using the iTRAQ/MRM approach. J. Transl. Med. 2018, 16, 11. [CrossRef]

79. Pham, T.K.; Roy, S.; Noirel, J.; Douglas, I.; Wright, P.C.; Stafford, G.P. A quantitative proteomic analysis of biofilm adaptation by the periodontal pathogen Tannerella forsythia. Proteomics 2010, 10, 3130-3141. [CrossRef]

80. Zhang, F. Application of machine learning in CT images and X-rays of COVID-19 pneumonia. Medicine 2021, 100, e26855. [CrossRef] [PubMed]

81. Dimauro, G.; Deperte, F.; Maglietta, R.; Bove, M.; La Gioia, F.; Renò, V.; Simone, L.; Gelardi, M. A Novel Approach for Biofilm Detection Based on a Convolutional Neural Network. Electronics 2020, 9, 881. [CrossRef]

82. Xu, Y.; Li, C.; Jiang, Y.; Guo, M.; Yang, Y.; Yang, Y.; Yu, H. Electrochemical Impedance Spectroscopic Detection of E.coli with Machine Learning. J. Electrochem. Soc. 2020, 167, 047508. [CrossRef]

83. Buetti-Dinh, A.; Galli, V.; Bellenberg, S.; Ilie, O.; Herold, M.; Christel, S.; Boretska, M.; Pivkin, I.V.; Wilmes, P.; Sand, W.; et al. Deep neural networks outperform human expert's capacity in characterizing bioleaching bacterial biofilm composition. Biotechnol. Rep. 2019, 22, e00321. [CrossRef]

84. Chudzik, P.; Majumdar, S.; Calivá, F.; Al-Diri, B.; Hunter, A. Microaneurysm detection using fully convolutional neural networks. Comput. Methods Programs Biomed. 2018, 158, 185-192. [CrossRef] [PubMed] 
85. Guo, Y.; Budak, Ü.; Şengür, A. A novel retinal vessel detection approach based on multiple deep convolution neural networks. Comput. Methods Programs Biomed. 2018, 167, 43-48. [CrossRef] [PubMed]

86. Gelardi, M.; Passalacqua, G.; Fiorella, M.L.; Mosca, A.; Quaranta, N. Nasal cytology: The "infectious spot", an expression of a morphological-chromatic biofilm. Eur. J. Clin. Microbiol. Infect. Dis. 2011, 30, 1105-1109. [CrossRef] [PubMed]

87. Wong, P.-C.; Fan, T.-E.; Lee, Y.-L.; Lai, C.-Y.; Wu, J.-L.; Chang, L.-H.; Su, T.-Y. Detection and Identification of the Stages of DH5-Alpha Escherichia coli Biofilm Formation on Metal by Using an Artificial Intelligence System. Microscopy Microanal. 2021, 27, 1218-1225. [CrossRef]

88. Pobre, V.; Arraiano, C.M. Next generation sequencing analysis reveals that the ribonucleases RNase II, RNase R and PNPase affect bacterial motility and biofilm formation in E. coli. BMC Genom. 2015, 16, 72. [CrossRef] [PubMed]

89. Saramago, M.; Domingues, S.; Viegas, S.C.; Arraiano, C.M. Biofilm formation and antibiotic resistance in Salmonella Typhimurium are affected by different ribonucleases. J. Microbiol. Biotechnol. 2014, 24, 8-12. [CrossRef]

90. Cohen, D.; Mechold, U.; Nevenzal, H.; Yarmiyhu, Y.; Randall, T.E.; Bay, D.C.; Rich, J.D.; Parsek, M.R.; Kaever, V.; Harrison, J.J.; et al. Oligoribonuclease is a central feature of cyclic diguanylate signaling in Pseudomonas aeruginosa. Proc. Natl. Acad. Sci. USA 2015, 112, 11359-11364. [CrossRef]

91. Lehnik-Habrink, M.; Schaffer, M.; Mäder, U.; Diethmaier, C.; Herzberg, C.; Stülke, J. RNA processing in Bacillus subtilis: Identification of targets of the essential RNase Y. Mol. Microbiol. 2011, 81, 1459-1473. [CrossRef] [PubMed]

92. Baumgardt, K.; Charoenpanich, P.; McIntosh, M.; Schikora, A.; Stein, E.; Thalmann, S.; Kogel, K.H.; Klug, G.; Becker, A.; Evguenieva-Hackenberg, E. RNase E affects the expression of the acyl-homoserine lactone synthase gene sinI in Sinorhizobium meliloti. J. Bacteriol. 2014, 196, 1435-1447. [CrossRef] [PubMed]

93. Moreira, R.N.; Dressaire, C.; Barahona, S.; Galego, L.; Kaever, V.; Jenal, U.; Arraiano, C.M. BolA Is Required for the Accurate Regulation of c-di-GMP, a Central Player in Biofilm Formation. mBio 2017, 8, e00443-17. [CrossRef]

94. Obana, N.; Nakamura, K.; Nomura, N. Role of RNase Y in Clostridium perfringens mRNA Decay and Processing. J. Bacteriol. 2017, 199, e00703-16. [CrossRef]

95. Diallo, I.; Provost, P. RNA-Sequencing Analyses of Small Bacterial RNAs and their Emergence as Virulence Factors in HostPathogen Interactions. Int. J. Mol. Sci. 2020, 21, 1627. [CrossRef] [PubMed]

96. Chakravarty, S.; Massé, E. RNA-Dependent Regulation of Virulence in Pathogenic Bacteria. Front. Cell. Infect. Microbiol. 2019, 9, 337. [CrossRef]

97. Czaplewski, L.; Bax, R.; Clokie, M.; Dawson, M.; Fairhead, H.; Fischetti, V.A.; Foster, S.; Gilmore, B.F.; Hancock, R.E.; Harper, D.; et al. Alternatives to antibiotics-a pipeline portfolio review. Lancet Infect. Dis. 2016, 16, 239-251. [CrossRef]

98. Gebreyohannes, G.; Nyerere, A.; Bii, C.; Sbhatu, D.B. Challenges of intervention, treatment, and antibiotic resistance of biofilmforming microorganisms. Heliyon 2019, 5, e02192. [CrossRef] [PubMed]

99. Sharma, A.; Gupta, P.; Kumar, R.; Bhardwaj, A. dPABBs: A Novel in silico Approach for Predicting and Designing Anti-biofilm Peptides. Sci. Rep. 2016, 6, 21839. [CrossRef]

100. Porto, W.F.; Irazazabal, L.; Alves, E.S.F.; Ribeiro, S.M.; Matos, C.O.; Pires, Á.S.; Fensterseifer, I.C.M.; Miranda, V.J.; Haney, E.F.; Humblot, V.; et al. In silico optimization of a guava antimicrobial peptide enables combinatorial exploration for peptide design. Nat. Commun. 2018, 9, 1490. [CrossRef]

101. Di Luca, M.; Maccari, G.; Maisetta, G.; Batoni, G. BaAMPs: The database of biofilm-active antimicrobial peptides. Biofouling 2015, 31, 193-199. [CrossRef] [PubMed]

102. Gupta, S.; Sharma, A.K.; Jaiswal, S.K.; Sharma, V.K. Prediction of Biofilm Inhibiting Peptides: An In silico Approach. Front. Microbiol. 2016, 7, 949. [CrossRef]

103. Rajput, A.; Thakur, A.; Sharma, S.; Kumar, M. aBiofilm: A resource of anti-biofilm agents and their potential implications in targeting antibiotic drug resistance. Nucleic Acids Res. 2018, 46, D894-D900. [CrossRef]

104. Srivastava, G.N.; Malwe, A.S.; Sharma, A.K.; Shastri, V.; Hibare, K.; Sharma, V.K. Molib: A machine learning based classification tool for the prediction of biofilm inhibitory molecules. Genomics 2020, 112, 2823-2832. [CrossRef] [PubMed]

105. Correia, V.G.; Bonifácio, V.D.; Raje, V.P.; Casimiro, T.; Moutinho, G.; da Silva, C.L.; Pinho, M.G.; Aguiar-Ricardo, A. Oxazolinebased antimicrobial oligomers: Synthesis by CROP using supercritical $\mathrm{CO}_{2}$. Macromol. Biosci. 2011, 11, 1128-1137. [CrossRef]

106. Mil-Homens, D.; Martins, M.; Barbosa, J.; Serafim, G.; Sarmento, M.J.; Pires, R.F.; Rodrigues, V.; Bonifácio, V.D.B.; Pinto, S.N. Carbapenem-Resistant Klebsiella pneumoniae Clinical Isolates: In Vivo Virulence Assessment in Galleria mellonella and Potential Therapeutics by Polycationic Oligoethyleneimine. Antibiotics 2021, 10, 56. [CrossRef]

107. Venkatesh, M.; Barathi, V.A.; Goh, E.T.L.; Anggara, R.; Fazil, M.; Ng, A.J.Y.; Harini, S.; Aung, T.T.; Fox, S.J.; Liu, S.; et al. Antimicrobial Activity and Cell Selectivity of Synthetic and Biosynthetic Cationic Polymers. Antimicrob. Agents Chemother. 2017, 61, e00469-17. [CrossRef] [PubMed]

108. Kuroda, K.; Caputo, G.A.; DeGrado, W.F. The role of hydrophobicity in the antimicrobial and hemolytic activities of polymethacrylate derivatives. Chemistry 2009, 15, 1123-1133. [CrossRef] [PubMed]

109. Palermo, E.F.; Kuroda, K. Chemical structure of cationic groups in amphiphilic polymethacrylates modulates the antimicrobial and hemolytic activities. Biomacromolecules 2009, 10, 1416-1428. [CrossRef] [PubMed]

110. Carmona-Ribeiro, A.M.; de Melo Carrasco, L.D. Cationic antimicrobial polymers and their assemblies. Int. J. Mol. Sci. 2013, 14, 9906-9946. [CrossRef] [PubMed] 
111. Santos, M.R.E.; Mendonça, P.V.; Almeida, M.C.; Branco, R.; Serra, A.C.; Morais, P.V.; Coelho, J.F.J. Increasing the Antimicrobial Activity of Amphiphilic Cationic Copolymers by the Facile Synthesis of High Molecular Weight Stars by Supplemental Activator and Reducing Agent Atom Transfer Radical Polymerization. Biomacromolecules 2019, 20, 1146-1156. [CrossRef]

112. Gibney, K.A.; Sovadinova, I.; Lopez, A.I.; Urban, M.; Ridgway, Z.; Caputo, G.A.; Kuroda, K. Poly(ethylene imine)s as antimicrobial agents with selective activity. Macromol. Biosci. 2012, 12, 1279-1289. [CrossRef] [PubMed]

113. Cavaleiro, E.; Duarte, A.S.; Esteves, A.C.; Correia, A.; Whitcombe, M.J.; Piletska, E.V.; Piletsky, S.A.; Chianella, I. Novel linear polymers able to inhibit bacterial quorum sensing. Macromol. Biosci. 2015, 15, 647-656. [CrossRef]

114. Ferreira, M.; Ogren, M.; Dias, J.N.R.; Silva, M.; Gil, S.; Tavares, L.; Aires-da-Silva, F.; Gaspar, M.M.; Aguiar, S.I. Liposomes as Antibiotic Delivery Systems: A Promising Nanotechnological Strategy against Antimicrobial Resistance. Molecules 2021, $26,2047$. [CrossRef]

115. Forier, K.; Raemdonck, K.; De Smedt, S.C.; Demeester, J.; Coenye, T.; Braeckmans, K. Lipid and polymer nanoparticles for drug delivery to bacterial biofilms. J. Control. Release 2014, 190, 607-623. [CrossRef] [PubMed]

116. Arif, M.; Sharaf, M.; Samreen Khan, S.; Chi, Z.; Liu, C.G. Chitosan-based nanoparticles as delivery-carrier for promising antimicrobial glycolipid biosurfactant to improve the eradication rate of Helicobacter pylori biofilm. J. Biomater. Sci. Polym. Ed. 2021, 32, 813-832. [CrossRef] [PubMed]

117. Suci, P.A.; Berglund, D.L.; Liepold, L.; Brumfield, S.; Pitts, B.; Davison, W.; Oltrogge, L.; Hoyt, K.O.; Codd, S.; Stewart, P.S.; et al. High-density targeting of a viral multifunctional nanoplatform to a pathogenic, biofilm-forming bacterium. Chem. Biol. 2007, 14, 387-398. [CrossRef]

118. Huh, A.J.; Kwon, Y.J. “Nanoantibiotics”: A new paradigm for treating infectious diseases using nanomaterials in the antibiotics resistant era. J. Control. Release 2011, 156, 128-145. [CrossRef]

119. Warnes, S.L.; Caves, V.; Keevil, C.W. Mechanism of copper surface toxicity in Escherichia coli O157:H7 and Salmonella involves immediate membrane depolarization followed by slower rate of DNA destruction which differs from that observed for Grampositive bacteria. Environ. Microbiol. 2012, 14, 1730-1743. [CrossRef] [PubMed]

120. Wang, L.; Hu, C.; Shao, L. The antimicrobial activity of nanoparticles: Present situation and prospects for the future. Int. J. Nanomed. 2017, 12, 1227-1249. [CrossRef]

121. Hong, R.; Kang, T.Y.; Michels, C.A.; Gadura, N. Membrane lipid peroxidation in copper alloy-mediated contact killing of Escherichia coli. Appl. Environ. Microbiol. 2012, 78, 1776-1784. [CrossRef] [PubMed]

122. Espírito Santo, C.; Lam, E.W.; Elowsky, C.G.; Quaranta, D.; Domaille, D.W.; Chang, C.J.; Grass, G. Bacterial killing by dry metallic copper surfaces. Appl. Environ. Microbiol. 2011, 77, 794-802. [CrossRef]

123. Subbiahdoss, G.; Sharifi, S.; Grijpma, D.W.; Laurent, S.; van der Mei, H.C.; Mahmoudi, M.; Busscher, H.J. Magnetic targeting of surface-modified superparamagnetic iron oxide nanoparticles yields antibacterial efficacy against biofilms of gentamicin-resistant staphylococci. Acta Biomater. 2012, 8, 2047-2055. [CrossRef]

124. Egger, S.; Lehmann, R.P.; Height, M.J.; Loessner, M.J.; Schuppler, M. Antimicrobial properties of a novel silver-silica nanocomposite material. Appl. Environ. Microbiol. 2009, 75, 2973-2976. [CrossRef]

125. Iavicoli, I.; Fontana, L.; Leso, V.; Bergamaschi, A. The effects of nanomaterials as endocrine disruptors. Int. J. Mol. Sci. 2013, 14, 16732-16801. [CrossRef] [PubMed]

126. Tomane, S.; López-Maya, E.; Boujday, S.; Humblot, V.; Marrot, J.; Rabasso, N.; Castells-Gil, J.; Sicard, C.; Dolbecq, A.; Mialane, P.; et al. One-pot synthesis of a new generation of hybrid bisphosphonate polyoxometalate gold nanoparticles as antibiofilm agents. Nanoscale Adv. 2019, 11, 3400-3405. [CrossRef]

127. Rozenbaum, R.T.; Andrén, O.C.J.; van der Mei, H.C.; Woudstra, W.; Busscher, H.J.; Malkoch, M.; Sharma, P.K. Penetration and Accumulation of Dendrons with Different Peripheral Composition in Pseudomonas aeruginosa Biofilms. Nano Lett. 2019, 19, 4327-4333. [CrossRef]

128. Lam, S.J.; O’Brien-Simpson, N.M.; Pantarat, N.; Sulistio, A.; Wong, E.H.; Chen, Y.Y.; Lenzo, J.C.; Holden, J.A.; Blencowe, A.; Reynolds, E.C.; et al. Combating multidrug-resistant Gram-negative bacteria with structurally nanoengineered antimicrobial peptide polymers. Nat. Microbiol. 2016, 1, 16162. [CrossRef]

129. Imberty, A.; Wimmerová, M.; Mitchell, E.P.; Gilboa-Garber, N. Structures of the lectins from Pseudomonas aeruginosa: Insight into the molecular basis for host glycan recognition. Microbes Infect. 2004, 6, 221-228. [CrossRef]

130. Reymond, J.L.; Bergmann, M.; Darbre, T. Glycopeptide dendrimers as Pseudomonas aeruginosa biofilm inhibitors. Chem. Soc. Rev. 2013, 42, 4814-4822. [CrossRef] [PubMed]

131. Sánchez-López, E.; Gomes, D.; Esteruelas, G.; Bonilla, L.; Lopez-Machado, A.L.; Galindo, R.; Cano, A.; Espina, M.; Ettcheto, M.; Camins, A.; et al. Metal-Based Nanoparticles as Antimicrobial Agents: An Overview. Nanomaterials 2020, 10, 292. [CrossRef] [PubMed]

132. Yoon, K.Y.; Hoon Byeon, J.; Park, J.H.; Hwang, J. Susceptibility constants of Escherichia coli and Bacillus subtilis to silver and copper nanoparticles. Sci. Total Environ. 2007, 373, 572-575. [CrossRef]

133. Lansdown, A.B. Silver. I: Its antibacterial properties and mechanism of action. J. Wound Care 2002, 11, 125-130. [CrossRef]

134. Singh, B.R.; Singh, B.N.; Singh, A.; Khan, W.; Naqvi, A.H.; Singh, H.B. Mycofabricated biosilver nanoparticles interrupt Pseudomonas aeruginosa quorum sensing systems. Sci. Rep. 2015, 5, 13719. [CrossRef] [PubMed]

135. Bhattacharyya, P.; Agarwal, B.; Goswami, M.; Maiti, D.; Baruah, S.; Tribedi, P. Zinc oxide nanoparticle inhibits the biofilm formation of Streptococcus pneumoniae. Antonie Van Leeuwenhoek 2018, 111, 89-99. [CrossRef] [PubMed] 
136. Kim, B.; Kim, D.; Cho, D.; Cho, S. Bactericidal effect of $\mathrm{TiO}_{2}$ photocatalyst on selected food-borne pathogenic bacteria. Chemosphere 2003, 52, 277-281. [CrossRef]

137. Jesline, A.; John, N.P.; Narayanan, P.M.; Vani, C.; Murugan, S. Antimicrobial activity of zinc and titanium dioxide nanoparticles against biofilm-producing methicillin-resistant Staphylococcus aureus. Appl. Nanosci. 2015, 5, 157-162. [CrossRef]

138. Ge, L.; Li, Q.; Wang, M.; Ouyang, J.; Li, X.; Xing, M.M. Nanosilver particles in medical applications: Synthesis, performance, and toxicity. Int. J. Nanomed. 2014, 9, 2399-2407. [CrossRef]

139. Bapat, P.; Singh, G.; Nobile, C.J. Visible Lights Combined with Photosensitizing Compounds Are Effective against Candida albicans Biofilms. Microorganisms 2021, 9, 500. [CrossRef] [PubMed]

140. Luke-Marshall, N.R.; Hansen, L.A.; Shafirstein, G.; Campagnari, A.A. Antimicrobial Photodynamic Therapy with Chlorin e6 Is Bactericidal against Biofilms of the Primary Human Otopathogens. mSphere 2020, 5, e00492-20. [CrossRef]

141. Biel, M.A. Photodynamic therapy of bacterial and fungal biofilm infections. Methods Mol. Biol. 2010, 635, 175-194. [CrossRef] [PubMed]

142. Hu, X.; Huang, Y.-Y.; Wang, Y.; Wang, X.; Hamblin, M.R. Antimicrobial Photodynamic Therapy to Control Clinically Relevant Biofilm Infections. Front. Microbiol. 2018, 9, 1299. [CrossRef] [PubMed]

143. Paramanantham, P.; Siddhardha, B.; Lal, S.S.; Sharan, A.; Alyousef, A.A.; Al Dosary, M.S.; Arshad, M.; Syed, A. Antimicrobial photodynamic therapy on Staphylococcus aureus and Escherichia coli using malachite green encapsulated mesoporous silica nanoparticles: An in vitro study. PeerJ 2019, 7, e7454. [CrossRef] [PubMed]

144. Nisbett, L.M.; Boon, E.M. Nitric Oxide Regulation of H-NOX Signaling Pathways in Bacteria. Biochemistry 2016, 55, 4873-4884. [CrossRef]

145. Hossain, S.; Nisbett, L.M.; Boon, E.M. Discovery of Two Bacterial Nitric Oxide-Responsive Proteins and Their Roles in Bacterial Biofilm Regulation. ACC Chem. Res. 2017, 50, 1633-1639. [CrossRef]

146. Barraud, N.; Storey, M.V.; Moore, Z.P.; Webb, J.S.; Rice, S.A.; Kjelleberg, S. Nitric oxide-mediated dispersal in single- and multi-species biofilms of clinically and industrially relevant microorganisms. Microb. Biotechnol. 2009, 2, 370-378. [CrossRef] [PubMed]

147. Nablo, B.J.; Schoenfisch, M.H. Antibacterial properties of nitric oxide-releasing sol-gels. J. Biomed. Mater. Res. A 2003, 67, 1276-1283. [CrossRef]

148. Duong, H.T.; Jung, K.; Kutty, S.K.; Agustina, S.; Adnan, N.N.; Basuki, J.S.; Kumar, N.; Davis, T.P.; Barraud, N.; Boyer, C. Nanoparticle (star polymer) delivery of nitric oxide effectively negates Pseudomonas aeruginosa biofilm formation. Biomacromolecules 2014, 15, 2583-2589. [CrossRef] [PubMed]

149. Adnan, N.N.M.; Sadrearhami, Z.; Bagheri, A.; Nguyen, T.K.; Wong, E.H.H.; Ho, K.K.K.; Lim, M.; Kumar, N.; Boyer, C. Exploiting the Versatility of Polydopamine-Coated Nanoparticles to Deliver Nitric Oxide and Combat Bacterial Biofilm. Macromol. Rapid Commun. 2018, 39, e1800159. [CrossRef] [PubMed]

150. Reffuveille, F.; Fuente-Núñez Cde, L.; Fairfull-Smith, K.E.; Hancock, R.E. Potentiation of ciprofloxacin action against Gramnegative bacterial biofilms by a nitroxide. Pathog. Dis. 2015, 73, ftv016. [CrossRef] [PubMed]

151. Verderosa, A.D.; Mansour, S.C.; de la Fuente-Núñez, C.; Hancock, R.E.; Fairfull-Smith, K.E. Synthesis and Evaluation of Ciprofloxacin-Nitroxide Conjugates as Anti-Biofilm Agents. Molecules 2016, 21, 841. [CrossRef] [PubMed]

152. Boase, N.R.B.; Torres, M.D.T.; Fletcher, N.L.; de la Fuente-Nunez, C.; Fairfull-Smith, K.E.Y. Polynitroxide copolymers to reduce biofilm fouling on surfaces. Polym. Chem. 2018, 9, 5308-5318. [CrossRef]

153. Flemming, H.C.; Wingender, J. The biofilm matrix. Nat. Rev. Microbiol. 2010, 8, 623-633. [CrossRef] [PubMed]

154. Donelli, G.; Francolini, I.; Romoli, D.; Guaglianone, E.; Piozzi, A.; Ragunath, C.; Kaplan, J.B. Synergistic activity of dispersin B and cefamandole nafate in inhibition of staphylococcal biofilm growth on polyurethanes. Antimicrob. Agents Chemother. 2007, 51, 2733-2740. [CrossRef] [PubMed]

155. Franklin, M.J.; Nivens, D.E.; Weadge, J.T.; Howell, P.L. Biosynthesis of the Pseudomonas aeruginosa Extracellular Polysaccharides, Alginate, Pel, and Psl. Front. Microbiol. 2011, 2, 167. [CrossRef] [PubMed]

156. Kaplan, J.B.; Mlynek, K.D.; Hettiarachchi, H.; Alamneh, Y.A.; Biggemann, L.; Zurawski, D.V.; Black, C.C.; Bane, C.E.; Kim, R.K.; Granick, M.S. Extracellular polymeric substance (EPS)-degrading enzymes reduce staphylococcal surface attachment and biocide resistance on pig skin in vivo. PLOS ONE 2018, 13, e0205526. [CrossRef]

157. Grassi, L.; Maisetta, G.; Esin, S.; Batoni, G. Combination Strategies to Enhance the Efficacy of Antimicrobial Peptides against Bacterial Biofilms. Front. Microbiol. 2017, 8, 2409. [CrossRef] [PubMed]

158. Jones, E.A.; McGillivary, G.; Bakaletz, L.O. Extracellular DNA within a nontypeable Haemophilus influenzae-induced biofilm binds human beta defensin-3 and reduces its antimicrobial activity. J. Innate Immun. 2013, 5, 24-38. [CrossRef] [PubMed]

159. Fanaei Pirlar, R.; Emaneini, M.; Beigverdi, R.; Banar, M.; van Leeuwen, W.B.; Jabalameli, F. Combinatorial effects of antibiotics and enzymes against dual-species Staphylococcus aureus and Pseudomonas aeruginosa biofilms in the wound-like medium. PLoS ONE 2020, 15, e0235093. [CrossRef] [PubMed]

160. Erskine, E.; MacPhee, C.E.; Stanley-Wall, N.R. Functional Amyloid and Other Protein Fibers in the Biofilm Matrix. J. Mol. Biol. 2018, 430, 3642-3656. [CrossRef] [PubMed]

161. Taglialegna, A.; Lasa, I.; Valle, J. Amyloid Structures as Biofilm Matrix Scaffolds. J. Bacteriol. 2016, 198, 2579-2588. [CrossRef] [PubMed] 
162. Chen, D.; Cao, Y.; Yu, L.; Tao, Y.; Zhou, Y.; Zhi, Q.; Lin, H. Characteristics and influencing factors of amyloid fibers in S. mutans biofilm. AMB Express 2019, 9, 31. [CrossRef] [PubMed]

163. Romero, D.; Sanabria-Valentín, E.; Vlamakis, H.; Kolter, R. Biofilm inhibitors that target amyloid proteins. Chem. Biol. 2013, 20, 102-110. [CrossRef]

164. Besingi, R.N.; Wenderska, I.B.; Senadheera, D.B.; Cvitkovitch, D.G.; Long, J.R.; Wen, Z.T.; Brady, L.J. Functional amyloids in Streptococcus mutans, their use as targets of biofilm inhibition and initial characterization of SMU_63c. Microbiology 2017, 163, 488-501. [CrossRef]

165. Branda, S.S.; Chu, F.; Kearns, D.B.; Losick, R.; Kolter, R. A major protein component of the Bacillus subtilis biofilm matrix. Mol. Microbiol. 2006, 59, 1229-1238. [CrossRef] [PubMed]

166. Lopez, D.; Koch, G. Exploring functional membrane microdomains in bacteria: An overview. Curr. Opin. Microbiol. 2017, 36, 76-84. [CrossRef] [PubMed]

167. García-Fernández, E.; Koch, G.; Wagner, R.M.; Fekete, A.; Stengel, S.T.; Schneider, J.; Mielich-Süss, B.; Geibel, S.; Markert, S.M.; Stigloher, C.; et al. Membrane Microdomain Disassembly Inhibits MRSA Antibiotic Resistance. Cell 2017, 171, 1354-1367.e20. [CrossRef] [PubMed]

168. Bramkamp, M.; Lopez, D. Exploring the existence of lipid rafts in bacteria. Microbiol. Mol. Biol. Rev. 2015, 79, 81-100. [CrossRef]

169. López, D.; Kolter, R. Functional microdomains in bacterial membranes. Genes Dev. 2010, 24, 1893-1902. [CrossRef]

170. Dempwolff, F.; Möller, H.M.; Graumann, P.L. Synthetic motility and cell shape defects associated with deletions of flotillin/reggie paralogs in Bacillus subtilis and interplay of these proteins with NfeD proteins. J. Bacteriol. 2012, 194, 4652-4661. [CrossRef] [PubMed]

171. Sun, Y.; Zhao, C.; Niu, J.; Ren, J.; Qu, X. Colorimetric Band-aids for Point-of-Care Sensing and Treating Bacterial Infection. ACS Cent. Sci. 2020, 6, 207-212. [CrossRef] [PubMed]

172. Hu, W.; Peng, C.; Luo, W.; Lv, M.; Li, X.; Li, D.; Huang, Q.; Fan, C. Graphene-based antibacterial paper. ACS Nano 2010, 4 , 4317-4323. [CrossRef]

173. Deiss, F.; Funes-Huacca, M.E.; Bal, J.; Tjhung, K.F.; Derda, R. Antimicrobial susceptibility assays in paper-based portable culture devices. Lab. Chip 2014, 14, 167-171. [CrossRef]

174. Boehle, K.E.; Gilliand, J.; Wheeldon, C.R.; Holder, A.; Adkins, J.A.; Geiss, B.J.; Ryan, E.P.; Henry, C.S. Utilizing Paper-Based Devices for Antimicrobial-Resistant Bacteria Detection. Angew. Chem. Int. Ed. Engl. 2017, 56, 6886-6890. [CrossRef] [PubMed] 